\title{
Agderia - a postglacial lost land in the southern Norwegian North Sea
}

\author{
Øyvind Hammer ${ }^{1}$, Sverre Planke ${ }^{2,3}$, Amer Hafeez ${ }^{2,4}$, Berit O. Hjelstuen ${ }^{5}$, Jan I. Faleide ${ }^{3}$ \\ \& Frode Kvalø $\varnothing^{6}$
}

\author{
${ }^{1}$ Natural History Museum, University of Oslo, Box 1172 Blindern, 0318 Oslo, Norway. \\ ${ }^{2}$ Volcanic Basin Petroleum Research as (VBPR), Oslo Science Park, 0349 Oslo, Norway. \\ ${ }^{3}$ Centre for Earth Evolution and Dynamics (CEED), University of Oslo, Box 1028 Blindern, 0315 Oslo, Norway. \\ ${ }^{4}$ Tullow Oil Norway, Tordenskiolds gate 6B, 0160 Oslo, Norway. \\ ${ }^{5}$ Department of Earth Science, University of Bergen, Allégt. 41, 5007 Bergen, Norway. \\ ${ }^{6}$ Norwegian Maritime Museum, Bygdøynesveien 37, N-0286 Oslo, Norway. \\ E-mail corresponding author (Øyvind Hammer):ohammer@nhm.uio.no
}

Large continental shelf areas, presently submerged, were dry land during the last glacial maximum and early postglacial time. These 'lost worlds' are of outstanding interest because they are believed to have played a central role in animal and plant biogeography, and particularly human migration and cultural development. The large postglacial land area in the North Sea, known as Doggerland, has been studied in the British, Dutch and Danish sectors, but there is a gap in our knowledge in the Norwegian sector. By the compilation and interpretation of recent geophysical data (3D seismic data, high- and ultrahigh-resolution seismics, and bathymetry) and core data (sedimentology, micro- and macropaleontology, palynology, radiocarbon dating) we review the present knowledge about postglacial paleogeography in this area. In our limited core material, the terrestrial phase is represented by a hiatus or possibly by glaciolacustrine sediments, capped by $0.4-2.6 \mathrm{~m}$ of marine Holocene sand. We document marine transgression in the area at around 10-11 kyr cal BP. By analogy with similar areas such as Beringia, and with reference to archeological finds in Vest-Agder, Norway, we suggest the name Agderia for the Norwegian part of Doggerland.

Keywords: Doggerland, paleolandscape, habitability, seismics, paleontology

Received 14. August 2015 / Accepted 11. February 2016 / Published online 5. April 2016

\section{Introduction}

Large areas of the continental shelves around the world were dry land during the Last Glacial Maximum (LGM), and were flooded during the sea-level rise in the latest Pleistocene or Early Holocene. It is becoming clear that these areas played fundamental roles for the dispersal and evolution of plants, animals and humans in the Quaternary. Prominent examples of such 'lost lands' are Sundaland, connecting the Malay Peninsula to Borneo, Java and Sumatra (Bird et al., 2005); Beringia, connecting Asia to America over the Bering Strait (West, 1996), and Dog- gerland (Fig. 1), forming a land bridge from Great Britain to mainland Europe (Gaffney et al., 2009).

Gaffney et al. (2007) published a comprehensive study of the paleolandscapes of Doggerland in the southern North Sea. Their 23,000 $\mathrm{km}^{2}$ study area is located in the UK sector of the North Sea focusing on the Doggerbank (Fig. 1). Their study used a combination of industry 3D seismic data, high-resolution seismic and other geophysical data, and shallow cores and metadata from the British Geological Survey and other public sources. The integrated interpretation revealed a large prehistoric

Hammer, Ø., Planke, S., Hafeez, A., Hjelstuen, B.O., Faleide, J.I. \& Kvalø, F. 2015: Agderia - a postglacial lost land in the southern Norwegian North Sea. Norwegian Journal of Geology 96, 43-60. http://dx.doi.org/10.17850/njg96-1-05. 


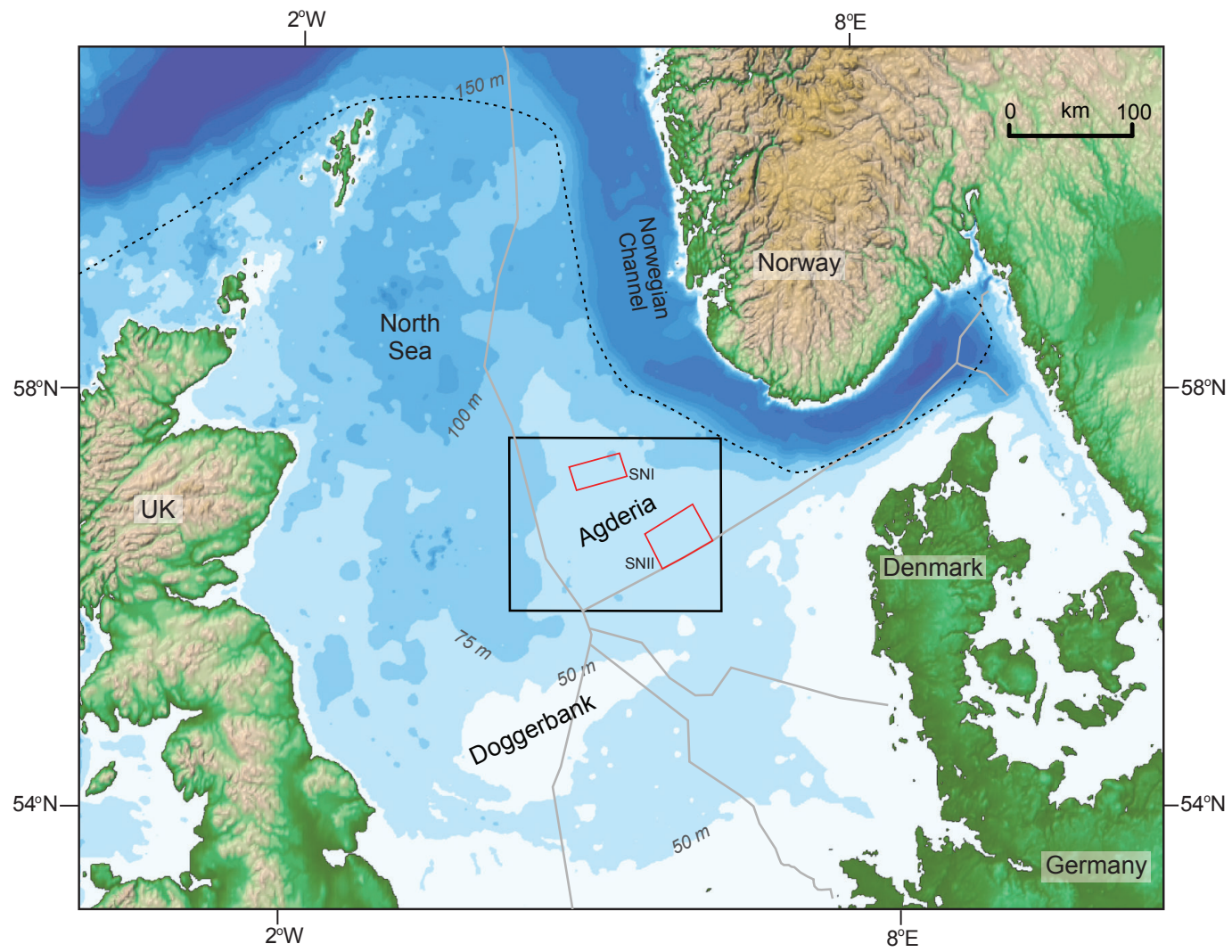

Figure 1. Bathymetric map of the North Sea based on the GEBCO database. The contour interval is $25 \mathrm{~m}$. The study area and the two focus areas SNI and SNII are shown as red boxes. The dotted black line shows the maximum hypothetical extent of Doggerland during the Weichselian, based on Coles (1998).

landscape (Fitch et al., 2005; Gaffney et al., 2007, 2009); however, there are major uncertainties in the Holocene paleolandscape model due to limited high- and ultrahigh-resolution data and few suitable cores. Research on Doggerland in the British and Danish sectors has focused on identifying optimal sites for human habitation, e.g., by the shorelines of sea and lakes, on riverbanks and on highs (Coles, 1998; Gaffney et al., 2007, 2009; Bicket, 2011; Grøn \& Mortensen, 2011). The documentation of dry land and the paleoenvironmental characterisation are important both for selecting targets of archeological investigations and for conservation policy.

Parts of the Norwegian continental shelf were also dry land with potential for human settlement after the last ice age (e.g., Lambeck, 1995). This area probably played a role in the development of human culture in northern Europe, possibly including Norway, although Glørstad (2016) favoured an early Holocene immigration route to southern Norway via present-day Sweden. In contrast to the adjacent Doggerland in the British, Danish and Dutch sectors, the possible postglacial dry land in the Norwegian sector has been little studied. An improved knowledge of human habitability at the time is required in order to guide development of seafloor installations and marine archeological studies.
'Lost lands' are conventionally named after adjacent localities (e.g., Beringia, Sundaland, Zealandia). The recent find of well-preserved human remains below sea level in Søgne, Vest-Agder, dated to c. $9.7 \mathrm{kyr}$ cal BP (8.6 ka BP uncalibrated; Sellevold \& Skar, 1999; Nymoen \& Skar, 2011), demonstrates human presence in southernmost Norway contemporary with the late phase of Doggerland. Although the two land areas were separated by the Norwegian Channel, we suggest honouring this find by giving the name Agderia to the Norwegian part of Doggerland (Fig. 1).

A research project on the postglacial development of the continental shelf in the southern Norwegian North Sea and the handling of future archeological finds was funded in 2011 (Glørstad \& Kvalø, 2012). We will here present some results of the marine geological investigations from this project, which was based on existing geophysical data and core material, to develop a paleogeographic model and to identify important data gaps. Following the approach used in the British sector (Gaffney et al., 2007) an important goal was to assess the potential for human habitability. 


\section{Background and geological setting}

The study area lies in the southern part of the Norwegian sector of the North Sea, covering an area of approximately 50,000 $\mathrm{km}^{2}$ (Fig. 1). The two focus areas are Sørlige Nordsjø I (SNI; 1,400 $\mathrm{km}^{2}$ ) and Sørlige Nordsjø II (SNII; 2,500 $\mathrm{km}^{2}$ ), identified as areas suitable for wind farming in the Havvind report (www.nve.no/Havvind). These areas are close to the classical fishing grounds of Store and Lille Fiskebank. The water depth ranges from 45 to $120 \mathrm{~m}$, with the maximum depth in the northeast close to the Norwegian Channel. In the focus areas, SNI and SNII, the water depth ranges from 50 to $70 \mathrm{~m}$.

Graham et al. (2011) reviewed the Quaternary stratigraphy and glaciation history of the North Sea basin. Continental ice sheets expanded into the North Sea during the Mid Pleistocene, with extensive ice cover during the glaciations in Marine Isotope Stages (MIS) 10-8, 6 and 2. Both the central North Sea and the Norwegian Channel were covered by ice during the LGM, about 30 to 25 kyr BP (Sejrup et al., 2009, 2015). Deglaciation commenced in the central North Sea, with glacial cover and advances on the Norwegian and Scottish mainland until about 13,000 years ago.

A system of buried, Quaternary tunnel valleys has been mapped onshore and offshore in the UK (Cornwell \& Carruthers, 1986; Wingfield, 1990; Long, 1992; Praeg, 1996, 2003; Lonergan et al., 2006; Graham et al., 2007, 2010; Stewart \& Lonergan, 2011), Denmark (Huuse \& Lykke-Andersen, 2000; Huuse et al., 2001; Jørgensen et al., 2003; Jørgensen \& Sandersen, 2006; Møller et al., 2007; Kristensen et al., 2008; Krohn et al., 2009), Germany (Piotrowski, 1994; Gabriel et al., 2003; Kaiser et al., 2007), Netherlands (Kluiving et al., 2003; Beets et al., 2005) and Belgium (Liu et al., 1992), whereas little work has been done in the Norwegian sector of the North Sea. The tunnel valleys observed in the Danish North Sea are buried and have no surface expression. These valleys have been identified on high-resolution seismic data and have maximum depths of c. $300 \mathrm{~m}$ below sea floor (Huuse \& Lykke-Andersen, 2000).

Rivers, including the Rhine, Thames, Ouse, Elbe, Tweed and Dee, were flowing through Doggerland when it was a land bridge between Great Britain and mainland Europe in postglacial time. Lakes, rivers, fluvial channels and beaches can be identified as shallow seismic anomalies (Hovland \& Dukefoss, 1981; Wysota et al., 2002; Kolla et al., 2007; Kuhlmann \& Wong, 2008). However, shallow cores provide better insight into the sedimentary environment. Core data from the Heligoland Channel suggest that the marine transgression occurred between 11 and 8.6 kyr cal BP (Konradi, 2000), in agreement with core data from the nearby Borkum Riffgrund (Wolters et al., 2010) and Jyske Rev (Leth, 2003). The Dogger Bank was likely totally submerged at $6 \mathrm{kyr}$ cal BP (Shennan et al., 2000) or possibly drowned by the Storegga Slide tsunami at 8.2 kyr cal BP (Weninger et al., 2008). Other prominent near-surface features in the North Sea are piercing salt domes (e.g., Fitch et al., 2005), glacial plough marks and moraines (Graham et al., 2007, 2010).

\section{Data and methods}

In this study, the database comprises bathymetric records, seismic profiles and sediment cores. There is no central archive for shallow geophysical and geological data in Norway, and we have therefore collected these data from a number of private and public sources.

The southern Norwegian North Sea has been a focus of petroleum activities since the 1970s. It is therefore surprising that very little bathymetry, seabed soil samples, and high-resolution seismic data exist in this area. Much more research and studies have been conducted on the neighbouring UK, Danish, Dutch and German continental shelves (see Geological setting chapter), and intense geophysical, geological and ecological survey activities have been undertaken on the Doggerbank in preparation for wind-farm development (e.g., www.forewind.co.uk). Furthermore, there appears to be limited fishing activity in the two focus areas, as there are very few bathymetric track lines in the Olex database (see below).

The search for high-resolution bathymetric and seismic data has been time-consuming and difficult, as we have identified no major Norwegian databases with such information. The data are normally stored by the data owners, but are commonly discarded after some years. Our project database is not complete, though, as there exist, e.g., power-cable route survey data that we have not had access to within the project.

In contrast, there are abundant conventional $2 \mathrm{D}$ and $3 \mathrm{D}$ seismic data available in the study area. Information about the surveys are readily available from central data archives (http://www.npd.no/en/about-us/collaborationprojects/diskos/), and the project has been fortunate to obtain access to a very large 3D seismic data volume from the PGS central North Sea MegaSurvey. Development of new high-resolution 3D seismic acquisition technologies, such as the P-Cable 3D system (Planke \& Berndt, 2007), and new processing technologies, such as the PGS SWIM (Separated Wavefield Imaging), will allow for improved interpretation of the shallow geology in the North Sea in the future as more data become available.

\section{Bathymetry}

Little bathymetric data are available in the study area. The main databases (e.g., http://www.imr.no/forskning/ programmer/mareano/en) show no modern data in the area. A search for industry swath data along pipelines and submarine cables provided detailed information 
only along the Lista-Valhall cable route (side-scan sonar, pinger, multi-beam echo sounder, shallow coring).

We have had access to the shared bathymetry database of Olex (www.olex.no), commonly used by fishing and research vessels. The Olex database is gridded with $5 \mathrm{~m}$ resolution and $10 \mathrm{~m}$ positional accuracy (GPS). Unfortunately, the Olex coverage is poor in the study area, precluding any detection of local seabed features.

The large-scale bathymetry shown in Fig. 1 is based on the General Bathymetric Chart of the Oceans, gridded to 30 arc seconds (http://www.gebco.net).

\section{Seismic data}

A dense grid of conventional $2 \mathrm{D}$ and $3 \mathrm{D}$ seismic reflection data is available for the study area (PetroBank www.pdp.discos.com). PGS has the most extensive 3D seismic coverage in the study area. They have merged numerous 3D surveys into 'MegaSurveys' with consistent data quality and excellent spatial coverage. The 'Mapping Doggerland' project (Gaffney et al., 2007) was to a large degree based on the PGS southern North Sea MegaSurvey, and a significant part of our study area is covered by the central North Sea MegaSurvey. PGS granted us access to the uppermost second of data from the central North Sea MegaSurvey. The data volume covers $29,000 \mathrm{~km}^{2}$. The $3 \mathrm{D}$ data coverage for SNI and SNII is 900 and 2,000 $\mathrm{km} 2$, respectively (Fig. 2).

High- and ultrahigh-resolution seismic data are commonly acquired for geotechnical surveys. Access to these data requires direct contact with the data owners. We have been granted access to six high-resolution, deep tow sparker profiles around well 3/6-1 by Eni, and pinger and side-scan sonar data examples from the Valhall Redevelopment Project Cable Route Survey (Fig. 2).

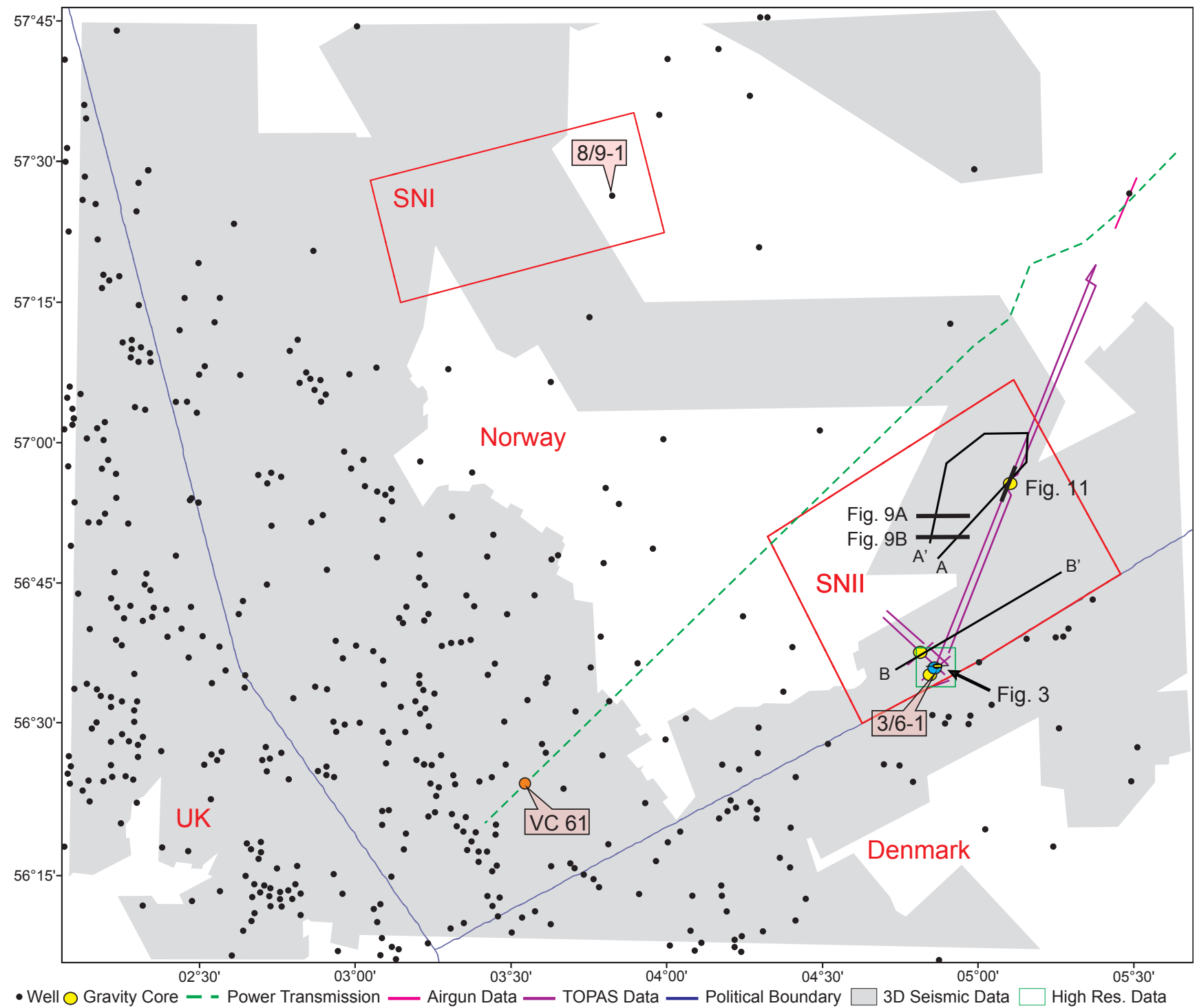

Figure 2. Map showing the 3D seismic data coverage, boreholes and the main study areas SNI and SNII. 
The seismic and cultural data were interpreted with the IHS Kingdom Suite software (seismicmicro.com). Initially, the seabed horizon was manually picked on arbitrary lines and selected cross-lines and in-lines. 2D or 3D hunt interpretation was not possible because the seabed is extremely variable in both amplitude and phase. The horizon was subsequently gridded using Flexible and Spline gridding functions, followed by horizon snap to grid. Horizon and volume attributes such as amplitude envelope and volume RMS were calculated. It is difficult to interpret any shallow horizons with confidence in the study area. Interpretation was therefore done mainly on horizon time slices and attribute maps. Time slices were generated at different depths to look for fluvial channels, tunnel valleys, coastlines, sand banks, estuary, salt domes and gas chimneys.

Additional ultrahigh-resolution data were acquired for this project during a University of Bergen (UiB) research cruise onboard the R/V G.O. Sars in June 2012 (Hjelstuen et al., 2012). We here report results from a Kongsberg TOPAS PS18 parametric subbottom profiling in the SNII area (Fig. 2). The profiler was used in the chirp mode, with a resolution better than $0.3 \mathrm{~m}$.

The different characteristics of conventional 3D, highresolution $2 \mathrm{D}$ and ultrahigh-resolution deep tow $2 \mathrm{D}$ data are evident in lines around well 3/6-1 (Fig. 3). Shallow reflections in the uppermost 100 metres, down to about $0.12 \mathrm{~s}$ below the sea floor, are discontinuous and problematic to map in the conventional and high-resolution data. A high-amplitude reflection is clearly imaged about $2.5 \mathrm{~m}$ below the sea floor in the ultrahigh-resolution data. This event correlates with the transition from Holocene marine to Late Weichselian glaciolacustrine clays (Fig. 4). However, the event is too shallow to be resolved on the conventional and high-resolution data so it is not possible to map thickness variations of the Holocene sequence in the SNII area.

The seismic imaging improves significantly below 0.2 s, about $160 \mathrm{~m}$ below the sea surface. Major elongated channels and semi-circular salt domes are interpreted with high confidence in this interval from 0.2 to $0.5 \mathrm{~s}$ (c. 160 to $410 \mathrm{~m}$ depth) both in cross-sections and on time horizons. We have therefore mapped out the distribution of paleochannels (so-called tunnel valleys or buried valleys), salt domes and associated features in the uppermost $0.5 \mathrm{~s}$ of the $3 \mathrm{D}$ cube.

\section{Seabed samples and sediment cores}

Information from seabed samples and sediment cores are sparse in the study area. One petroleum well has been drilled in each of the focus areas (Fig. 2). Well 8/9-1 is located in the SNI area (Fig. 2) and was drilled in 1976. No data are available from this well site. Well 3/6-1 was drilled in the southern part of the SNII area in 2000. A
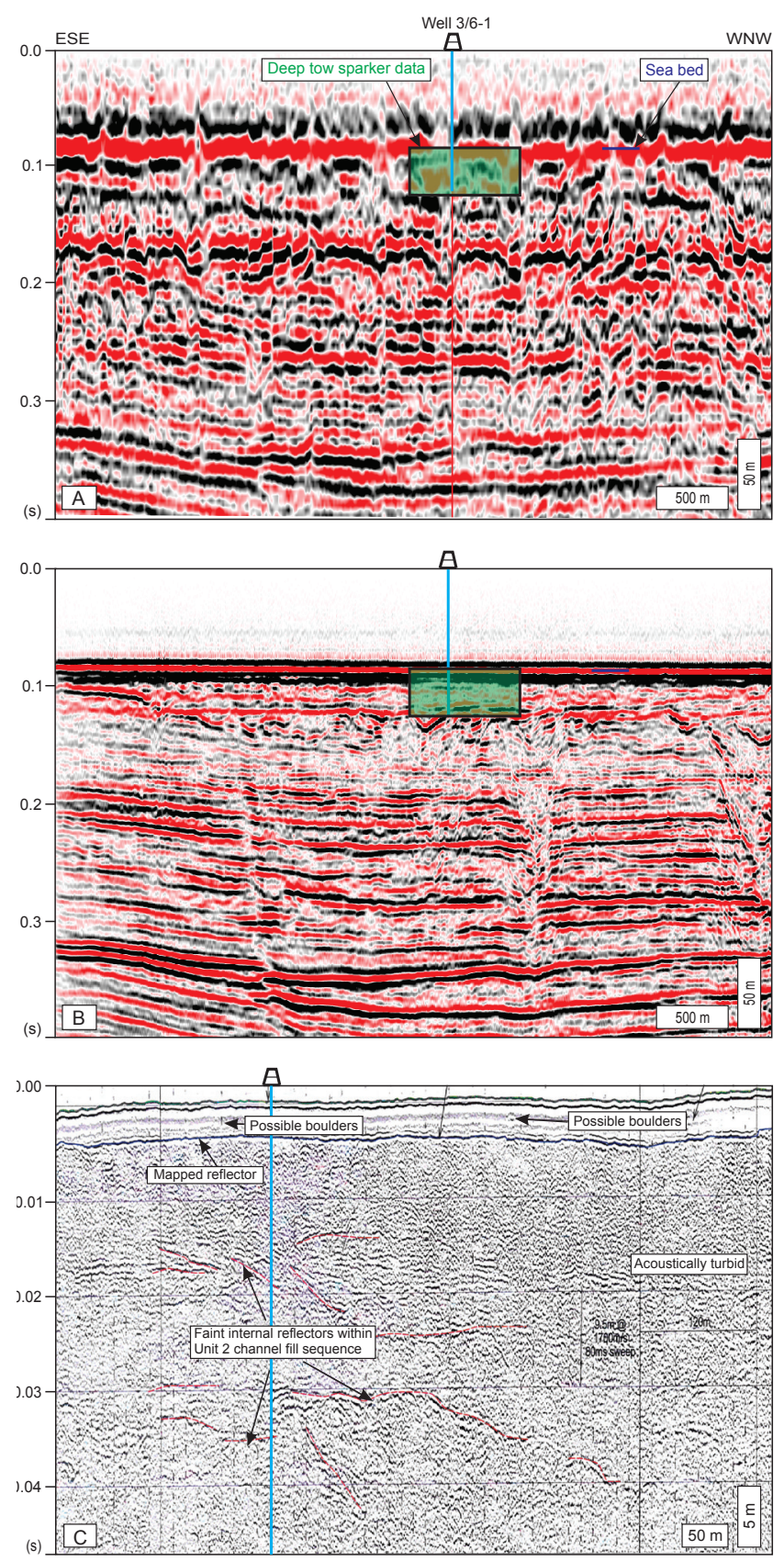

Figure 3. Comparison of (A) conventional 3D, (B) high-resolution, and $(C)$ ultrahigh-resolution seismic data along NA001-D204. The profile is located in Fig. 2. Note the difference in horizontal scale; (A) and $(B)$ show the complete $5 \mathrm{~km}$ profile while $(C)$ represents an 800 $m$ subprofile around 3/6-1.

soil boring was made to $37 \mathrm{~m}$ below seabed, in preparation for installing a jack-up rig in the SNII area. Borehole results from Eni include a geotechnical report (Fugro, 2000) and a foraminiferal analysis report (Knudsen, 2000). Samples were taken at 1 to $2 \mathrm{~m}$ intervals from this boring, and remaining material after the sampling analysis was made available for this study by NGU.

In addition, we obtained access to a short vibrocore, Gardline VC61 (56²3.184’ N, 3³1.350’ E; Fig. 2), col- 
lected from a water depth of $68 \mathrm{~m}, 65 \mathrm{~km}$ southwest of the SNII area. The penetration was $1.40 \mathrm{~m}$ but recovery only $0.65 \mathrm{~m}$.

Gravity coring and partly vibrocoring is challenging in this area because of the Holocene cover of relatively coarse sand. During the $R / V$ G. O. Sars cruise in 2012 (Hjelstuen et al., 2012), repeated gravity coring was attempted in the SNII area (Fig. 2), with practically no recovery. Only sediment with grain size and fauna typical of the modern North Sea was found in this material.

\section{Analysis of the cores}

Seven dry samples from well 3/6-1 (Table 1; Figs. 4, 5) and samples from every $2 \mathrm{~cm}$ in VC61 were investigated at the University of Oslo. The samples were wet sieved at $63 \mu \mathrm{m}, 125 \mu \mathrm{m}, 250 \mu \mathrm{m}, 500 \mu \mathrm{m}$ and $1 \mathrm{~mm}$. The fine fraction $(<63 \mu \mathrm{m})$ was not analysed. The fractions were dried and weighed before fossils (macro- and microfauna) were identified and described.

Shell fragments and fossils from four samples in 3/6-1 were dated with AMS at the radiocarbon Dating Laboratory, University of Lund, Sweden, based on a half time of
5,568 years (Table 1). Ages are reported both uncalibrated and calibrated. Calibrations were calculated with Calib 7.0 (Stuiver et al., 2005) and the Marine13 calibration curve (Reimer et al., 2013), which includes a globally averaged marine reservoir correction. A local correction (Delta R) was not used because the modern value cannot be applied to the completely different hydrographic conditions of the Weichselian to Early Holocene of the North Sea. This implies an additional uncertainty of 2-300 years.

The identity of some mineral grains in the 3/6-1 samples was checked by XRD at the Natural History Museum, Oslo, whereas the palynology of four other samples from the same well was analysed by TNO, Utrecht, Netherlands (Table 1; Donders et al., 2011). These samples were treated according to the TNO standard laboratory protocol for Quaternary sediments, involving sieving at $7 \mu \mathrm{m}$, acetolysis and heavy liquid flotation. All the samples yielded considerable amounts of relatively well preserved palynomorphs (pollen, spores, dinoflagellates and foraminifera).

The new results from the 3/6-1 material have been integrated with the results from the previous studies (Fugro, 2000; Knudsen, 2000), as detailed below.

Table 1. Studied core material and analyses.

\begin{tabular}{l|c|c|c|c}
\hline \multicolumn{1}{c|}{ Depth $(m)$} & Sample & Weight $(g)$ & ${ }^{14} \mathrm{C}$ & Palynology \\
\hline $1.00-1.75$ & 2B & 241 & $\mathrm{X}$ & $\mathrm{X}$ \\
$2.00-2.54$ & 3C & 166 & $\mathrm{X}$ & $\mathrm{X}$ \\
$3.03-3.15$ & $4 \mathrm{AB}$ & 108 & $\mathrm{X}$ & $\mathrm{X}$ \\
$5.20-5.27$ & $6 \mathrm{~B}$ & 104 & & $\mathrm{X}$ \\
$8.00-8.24$ & $9 \mathrm{~A}$ & 96.4 & & \\
$10.00-10.14$ & $11 \mathrm{~A}$ & 98.7 & $\mathrm{X}$ & \\
$13.50-13.60$ & $15 \mathrm{~A}$ & 51.5 & & \\
\hline
\end{tabular}

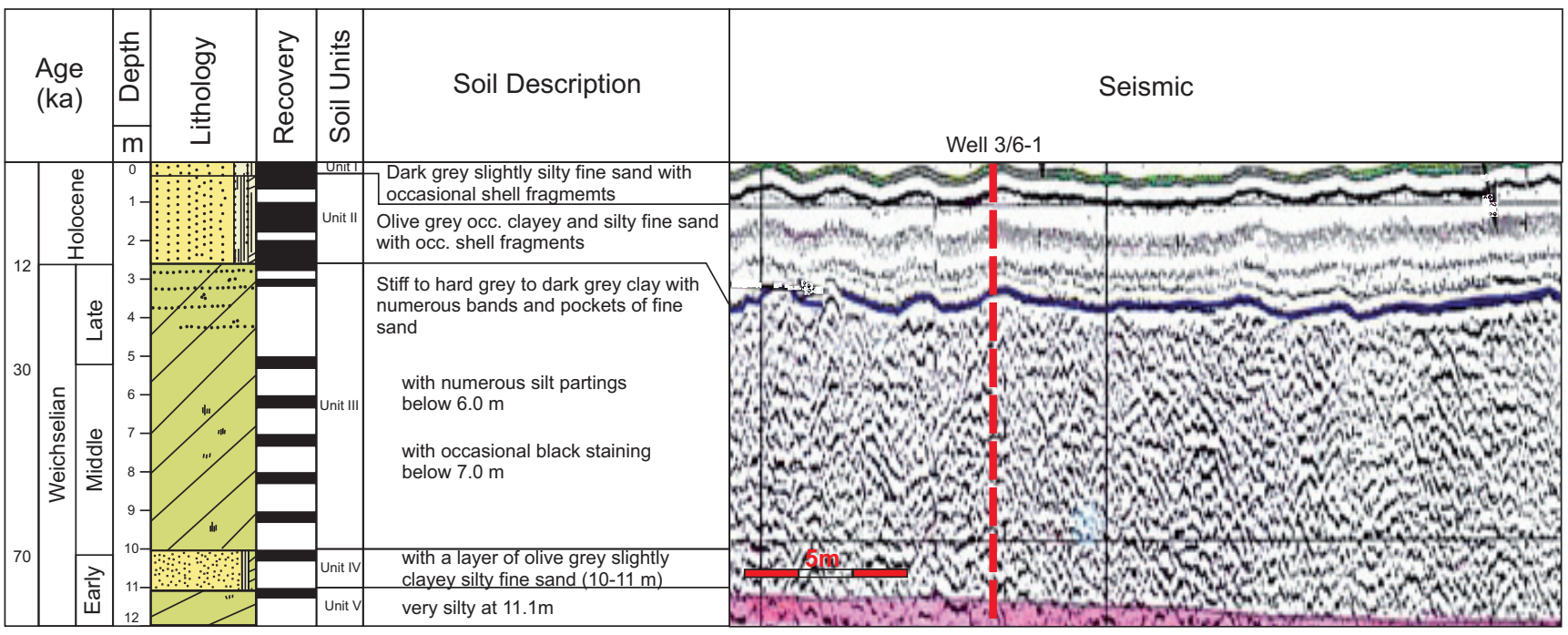

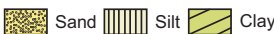

Figure 4. Borehole-seismic correlation for the 3/6-1 site. A high-amplitude reflection is seen in the deep tow sparker data at about $2.5 \mathrm{~m}$ below seafloor, separating a transparent unit (Holocene) from underlying scattered and semi-continuous dipping events. 


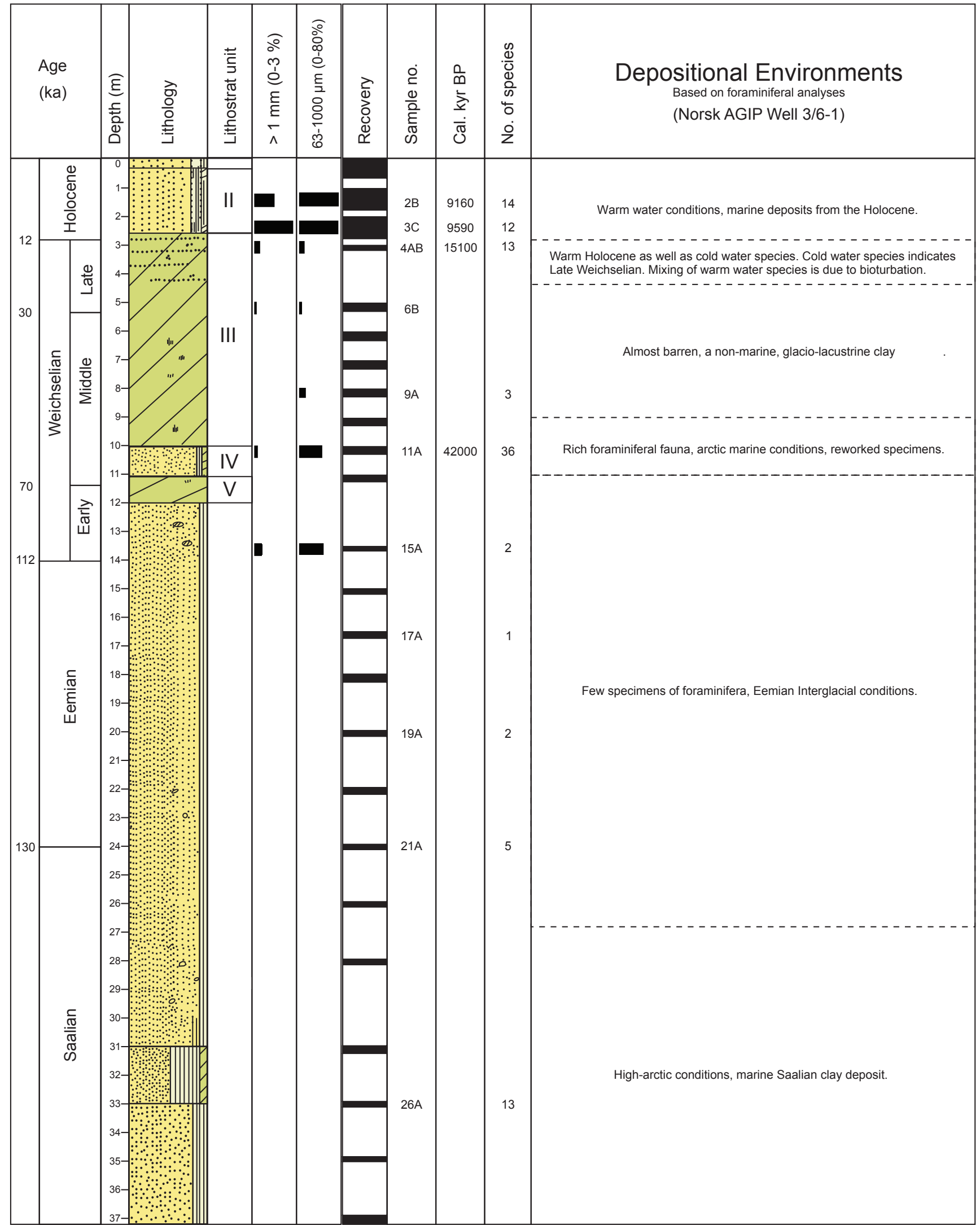

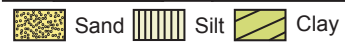

Figure 5. Summary stratigraphy of the geotechnical borehole at the well 3/6-1 site. Lithology and sampling intervals (recovery) based on Fugro (2000), depositional environment compiled from Knudsen (2000), and grain-size data and radiocarbon dates from this study. 


\section{Results}

Lithostratigraphy, sediment characteristics and paleontology

The upper $12 \mathrm{~m}$ in well 3/6-1 were sampled and divided into five subunits, Unit I-V, by Fugro (2000), cf., Knudsen (2000). This division is followed here (Figs. 4, 5).

Unit I, from 0.0 to $0.3 \mathrm{~m}$, consists of dark grey, slightly silty fine sand with sporadic shell fragments.

Unit II, from 0.3 to $2.6 \mathrm{~m}$, consists of olive grey, in part slightly clayey, silty fine sand with sporadic shell fragments. The base of this unit is marked clearly on the deep tow sparker data due to the strong impedance contrast of sand and underlying clays (Fig. 4). Fugro (2000) also reported a sharp transition in soil resistance slightly below that level. Two samples were analysed from Unit II.

Sample 2B (1.00-1.75 m, middle Unit II; Fig. 5) consists of poorly sorted, very fine sand. The coarsest fractions consist mainly of bivalves, but also abundant ice-rafted debris (IRD) mainly of mature lithology (quartz and chert). The shelly macrofauna is abundant, diverse and well preserved. Identified taxa include the bivalves Venus casina (sand and muddy sand from 7 to $180 \mathrm{~m}$ depth), Abra prismatica (mixed sand from lower shore to $60 \mathrm{~m}$ ), Tellina fabula (sand to muddy sand, middle intertidal to $55 \mathrm{~m}$ ), and the echinoid Echinocyamus pusillus (sand, lower intertidal to $1,250 \mathrm{~m}$ ). The foraminiferal fauna is abundant, with a warm-water aspect in accordance with Knudsen (2000), together with marine ostracods. A complete bivalve shell (Abra prismatica) was radiocarbon dated to $8,930 \pm 55{ }^{14} \mathrm{C}$ yrs BP, or c. 9,160 cal yrs BP (Table 2).

Sample 3C (2.00-2.54 m, lowermost Unit II) consists of poorly sorted, very fine sand (Fig. 5). Grain-size distribution is similar to sample $2 \mathrm{~B}$, with the coarser fraction dominated by shelly debris. The Ice Rafted Debris (IRD) is also of similar abundance and composition, but slightly less mature, with mica schist and feldspars as well as large chert clasts. The IRD provenance is interpreted as mixed, with crystalline bedrock from Norway or Sweden as well as (most likely) Cretaceous chert. The shelly macrofauna is abundant, but the shells are mostly fragmented. The assemblage is similar to Sample 2B, with Venus, tel- linaceans, gastropods and E. pusillus. The foraminiferal fauna is abundant, with a composition in accordance with Knudsen (2000). In addition, a single specimen of the relatively shallow-water species Ammonia beccarii was found. Ostracods are very common. A complete bivalve shell (Tellinacea) was dated to $9,240 \pm 55{ }^{14} \mathrm{C}$ yrs BP, or c. 9,590 kyr cal BP (Table 2), i.e., Early Holocene.

Unit III, from 2.6 to $10.0 \mathrm{~m}$, consists of stiff to hard, grey to dark grey clay with numerous bands and pockets of fine sand with numerous silt partings below $6 \mathrm{~m}$. There is occasional black staining below $7 \mathrm{~m}$. Three samples were analysed from this unit.

Sample 4AB (3.03-3.15 m, uppermost Unit III) consists of very poorly sorted medium silt (Fig. 5). The IRD includes large $(>5 \mathrm{~mm})$ subangular to angular clasts of mixed, mainly immature lithology (feldspars, sandstone, subordinate quartz). The abundant shelly debris (bivalves and echinoids) is fragmented into shell sand. The foraminiferal fauna is mainly as described by Knudsen (2000), dominated by Elphidium excavatum (typical glaciomarine) and subordinate Cassidulina reniforme (cold water) but with some contribution from warmer-water species, possibly reworked or downworked by bioturbation (some tests are opaque and abraded). In addition, we commonly found Cibicides spp. (8\%). This thick-shelled form may have been missed previously due to heavy liquid separation. Ostracods are less common than above; only six specimens were found. Bivalve fragments were dated to $13,440 \pm 80{ }^{14} \mathrm{C}$ yrs $\mathrm{BP}$, or c. $15.1 \mathrm{kyr}$ cal $\mathrm{BP}$ (Table 2), i.e., Oldest Dryas, latest Weichselian.

Sample 6B (5.20-5.27 m, middle of Unit III) consists of poorly sorted medium silt (Fig. 5). The IRD component is negligible $(0.03 \%)$, mainly small angular to subangular quartz grains with subordinate feldspar and mica schist. The sample also contains wood fragments and other small plant debris, and some echinoid spines. No other macrofossil fragments were found. Knudsen (2000) found no foraminifera in Sample 6B. We found 15 specimens: Cassidulina laevigata (3), C. reniforme (4), Elphidium cf. excavatum (5), Quinqueloculina sp. (1) and Cibicides sp. (2). C. reniforme, in particular, is a cold-water form. There are no obvious signs of reworking, with the Elphidium tests being brown, translucent and with fine sculpture. Two marine ostracods were found (one Rabilimis sp.). There was insufficient material for radiocarbon dating.

Table 2. Radiocarbon dates.

\begin{tabular}{l|c|c|c|c|c}
\hline Sample & Depth $(\mathrm{m})$ & Material & Weight & ${ }^{14}$ C age & Calibrated age, 95\% conf. \\
\hline 2B & $1.00-1.75$ & A.prismatica & $30 \mathrm{mg}$ & $8930 \pm 55 \mathrm{BP}$ & $9299-9019 \mathrm{BP}$ \\
3C & $2.00-2.54$ & Tellinacea & $50 \mathrm{mg}$ & $9240 \pm 55$ & $9746-9429$ \\
$4 \mathrm{AB}$ & $3.03-3.15$ & Bivalves & $56 \mathrm{mg}$ & $13440 \pm 80$ & $15432-14850$ \\
$11 \mathrm{~A}$ & $10.00-10.14$ & Coal & $4 \mathrm{mg}$ & $38400 \pm 1500$ & $44668-38909$ \\
\hline
\end{tabular}




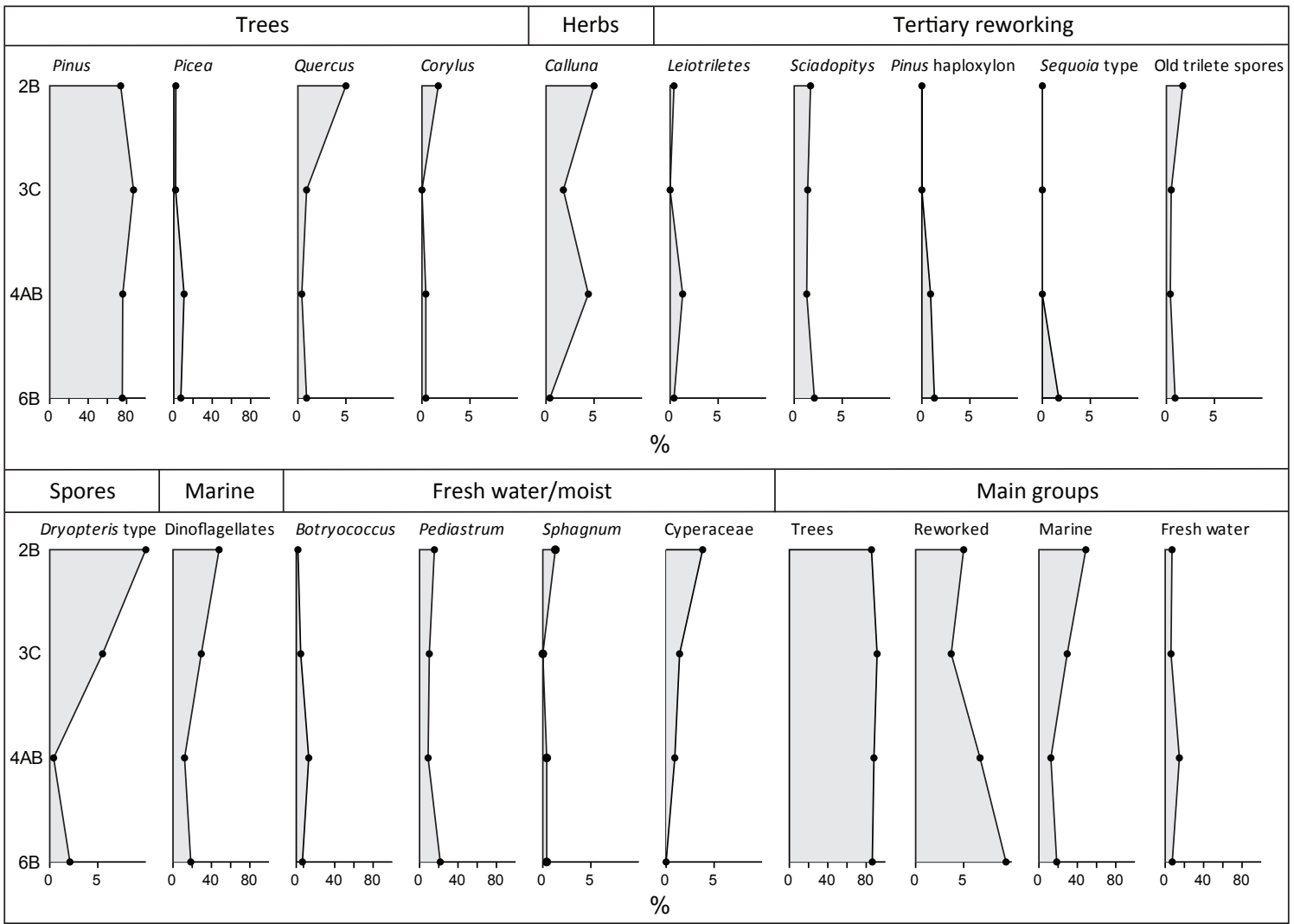

Figure 6. Palynology of four samples in core 3/6-1. Only taxa occurring in abundance greater than one percent are shown. The palynomorphs were extracted and identified by Donders et al. (2011).

Sample 9A (8.00-8.24 m, lowermost Unit III) consists of very poorly sorted medium silt (Fig. 5). There are no shelly fragments or IRD. The $>500 \mu \mathrm{m}$ fraction is dominated by gypsum crystals (confirmed by XRD). 17 foraminifera were found: C. reniforme (4), E. cf. excavatum (10), Cibicides sp. (2) and Lagena sp. (1). There was insufficient material for radiocarbon dating.

Unit IV, from 10.0-11.0 m, was described by Fugro (2000) as olive grey, slightly clayey, silty fine sand. One sample was analysed from this unit, sample 11A (10.00$10.14 \mathrm{~m}$, uppermost Unit IV), with very poorly sorted coarse silt (Fig. 5). The $>1 \mathrm{~mm}$ fraction does not contain IRD, but mainly large, bladed gypsum crystals. No shell fragments were observed. $4 \mathrm{mg}$ of coal particles were dated to $38,400 \pm 1,500{ }^{14} \mathrm{C}$ yrs BP, or c. $42 \mathrm{kyr}$ cal BP (Table 2), i.e., late Middle Weichselian, MIS 3.

Unit V, from 11.0-12.0 m, consists of hard grey clay. No samples were available from this unit, but sample 15A from the top of the underlying unit (13.50-13.60 m) contains very poorly sorted, very coarse silt (Fig. 5 ). The coarsest fractions contain sand clasts cemented by an unknown mineral. No shell fragments were identified.

The two uppermost samples 2B and 3C (Unit II), with a typical modern North Sea foraminiferal assemblage, form a group very distinct from samples $6 \mathrm{~B}, 9 \mathrm{~A}$ and $11 \mathrm{~A}$, with some typically colder species. The palynological data from the samples $2 \mathrm{~B}, 3 \mathrm{C}, 4 \mathrm{AB}$ and $6 \mathrm{~B}$, i.e., down to a core depth of $5.27 \mathrm{~m}$, are presented in Fig. 6. For this pollen scan a limited count was carried out, and the percentages are approximate. The pollen spectrum is dominated by pine (Pinus). Reworked Neogene pollen is present in all the studied samples but is particularly abundant in the two deeper samples (6B and $4 \mathrm{AB}$ ). Freshwater indicators are clearly present in the two deepest samples, while marine dinoflagellates are found in higher values in the top two samples, particularly in the uppermost sample. The assemblages indicate strong reworking of older deposits especially in the lower samples.

For core VC61, changes in grain size (Fig. 7) and microand macrofauna at $42 \mathrm{~cm}$ suggest a twofold division:

Unit A, $0-42 \mathrm{~cm}$ below seabed, consists of olive, silty sand with sporadic shell fragments. The core top is dark, brightening in steps down to $42 \mathrm{~cm}$, possibly because of reduction in the amount of organic material. The sediment is gradually coarsening downwards, partly because of shelly debris but also because of a small but downward increasing amount of angular gravel, interpreted as IRD. From 30 to $35 \mathrm{~cm}$ core depth some large $(>4 \mathrm{~mm})$ angular clasts of crystalline bedrock were identified. There are abundant shells and shelly fragments, mainly bivalves (including Astarte, Cerastoderma and Tellina), especially from 10 to $32 \mathrm{~cm}$ but continuing to $42 \mathrm{~cm}$. Barnea candida was found at $37 \mathrm{~cm}$, and Spisula elliptica at $41 \mathrm{~cm}$. 


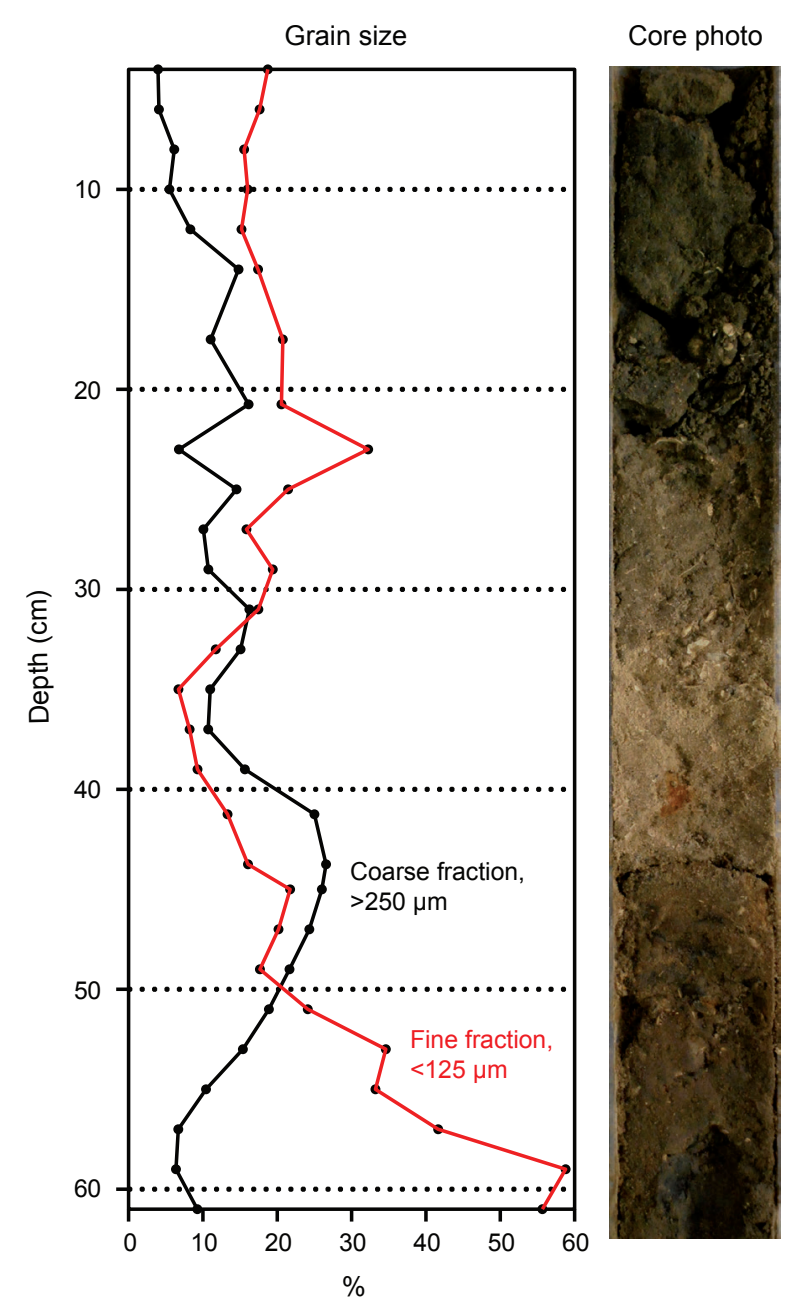

Figure 7. The Gardline VC61 core. Red curve: very fine sand, silt and clay $(<125 \mu \mathrm{m})$. Black: medium sand and coarser $(>250 \mu \mathrm{m})$. The dominant fraction (fine sand, 125-250 $\mu \mathrm{m}$ ) is not plotted. The core photo was taken with a standard camera.with stippled lines showing uncertainties. The last column indicates regional geodynamic events of the Barents Shelf and surrounding areas based on Otto \& Bailey (1995), Torsvik \& Andersen (2002), and Smelror et al. (2009).

Echinoid debris is also common. Foraminifera are sparse, but include Elphidium and Quinqueloculina in about equal proportions from core top to $40 \mathrm{~cm}$ core depth. Other foraminifera include Stainforthia and Polymorphina in the uppermost part and Cibicides at $33 \mathrm{~cm}$. The sublittoral gastropod Euspira cf. pulchella was found at 29 $\mathrm{cm}$.

Unit B, 42-62 cm below seabed, consists of grey, silty sand with pockets of stiff sandy clay in the lower part. Below $42 \mathrm{~cm}$ the sediment is again darker and more fine grained, with a thin vertical pipe of dark clay (from 43 to $57 \mathrm{~cm}$ ) associated with side branches and horizontal, saucer-shaped, clay beds, possibly flaser bedding. This unit has a more bimodal grain-size distribution, with substantial amounts of very coarse material (shells and IRD) as well as a downward increasing trend in the finest material, with up to $59 \%$ in the $<125 \mu \mathrm{m}$ fraction at the bottom of the core. Below $50 \mathrm{~cm}$ there are few IRD particles.
Elphidium sp. is common (monospecific) throughout. Bivalves in this unit are relatively common, but abraded and fragmented. They are all robust forms, with Mya sp. identified from a single chondrophore, and Arctica islandica from fragments.

\section{Seismic stratigraphy, seismic facies and seabed morphology}

The seabed reflection in the SNII area is a discontinuous, high-amplitude and low-frequency event with variable polarity. The water depth of the SNII area is 50-65 $\mathrm{m}$, but there are few bathymetric profiles available. The 3D seismic dataset was a PGS mega-merge. The long source-receiver offset, and muting and NMO stretch of the seafloor and shallow reflections, are the likely reasons for polarity reversal and phase shifts of some events in shallow water. Generally the data quality is good in the deeper sections, which is the main focus of the oil industry. Due to the noise and low resolution of the sea-floor reflection in the available conventional $2 \mathrm{D} / 3 \mathrm{D}$ seismic data, the reliability of the interpreted seafloor horizon is poor. However, channels up to several tens of metres deep have been identified. Seafloor attribute maps reveal clearer structures, interpreted as the surface expressions of salt domes and channels (Fig. 8).

At least five major channels with varying geometries are present in SNII. The bases of these incised valleys are erosive and very well defined on the seismic profiles. The channels have U- and V-shaped geometries with steeply dipping flanks. The uppermost parts of the channels are impossible to map due to the low quality of the shallow seismic interval. It is therefore not possible to determine accurately the stratigraphic age and the exact depth of the channels.

Channels show different types of infill patterns. Younger channels have erosive bases and deeper cutsinto stratigraphy than older channels (see Fig. 9 for seismic sections and Fig. 10A for location of channels). Two types of infill of the tunnel valleys can be discerned from the seismic facies analysis. A chaotic infill of the basal part of the channel is characterised by discontinuous and scattered reflections overlain by a draped infill pattern with parallel, continuous reflections (Fig. 9).

A prominent channel system is interpreted from time slices at different depths (Fig. 10). The width of the channel valleys is approximately $2 \mathrm{~km}$ and individual channels can be traced for $29 \mathrm{~km}$ in the study area. The channels in SNII have low sinuosity, and branching is commonly observed. The drainage pattern indicates a mainly braided and meandering pattern trending $\mathrm{E}-\mathrm{W}$ and NW-SE.

Two very distinct, $\mathrm{V}$-shaped narrow valleys are found in the time slice at $0.14 \mathrm{~s}$ depth (c. $45 \mathrm{~m}$ below the seafloor, 

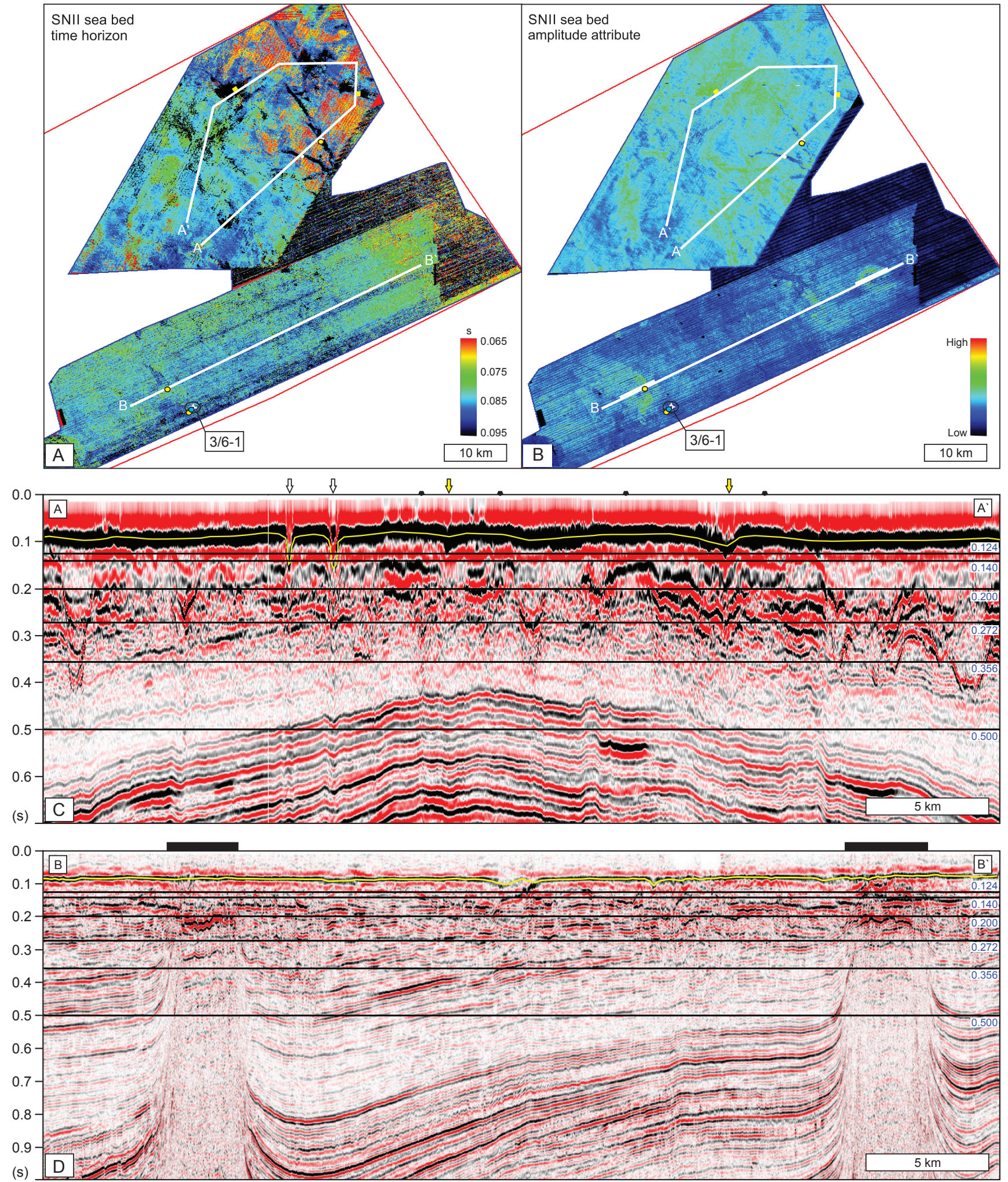

Depressions \& Channels \& Salt domes Bends •

Figure 8. Seabed time (A) and amplitude envelope attribute (B) maps of SNII. Distinct time and amplitude anomalies are seen on the maps even though the resolution of the seabed reflection is poor. Two arbitrary lines, $(C)$ and $(D)$, reveal seabed valleys and depressions, partly located above buried tunnel valleys, and distinct seafloor amplitude anomalies above two underlying salt domes. The locations of seismic profiles are also shown in Figs. 2 \& 10. The 0.140 s and 0.272 s time lines on both profiles correspond to time slices shown in Fig. 10. 

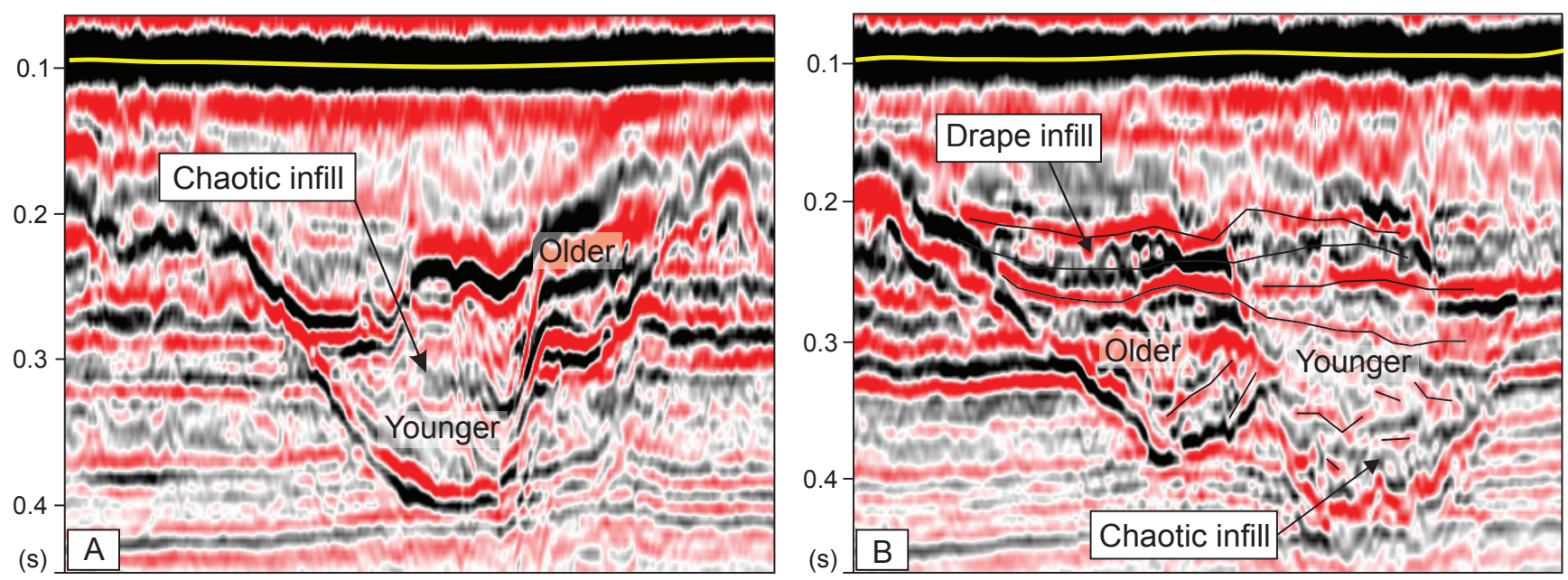

Figure 9. Channel facies variations revealing several generations of channel incision and infill. The locations of seismic profiles are shown in Figs. 2 \& 10B.

Figs. 10A, 11). These valleys have widths of $0.5 \mathrm{~km}$ and are approximately $1.0 \mathrm{~km}$ long, and can be analogues of Finger Lakes in the upstate New York (Fig. 10A). The TOPAS dataset (subbottom profiler line) across these V-shaped channels shows that the channels are all filled by acoustically laminated high-amplitude sediments. The strong bottom reflector indicates hard, sandy, seabed sediments.

The main channel has two meandering bends and a cutoff basin may have developed by a shifting of the channel (c. $155 \mathrm{~m}$ below the seafloor, Fig. 10B). Basins may also have developed in abandoned channels. No major channels can be identified in the southeastern part of the study area due to poor shallow seismic imaging. However, it is possible that a main channel was flowing across low-lying areas between two interpreted salt domes (Fig. 10B). It is not possible to say from these data if the channels and basins represent subaerial rivers and lakes, or subglacial features, but they resemble structures found in Doggerland in the British sector (Gaffney et al., 2007, 2009).

Another straight channel flowing from south to north has been identified, seemingly with a source area from a salt dome (Fig. 10B). Such straight channels are rare in nature and have great stability. The interpretation of time slices at various depths reveals the stability of this straight channel after its initiation.

No high- or ultrahigh-resolution seismic data or samples are available in SNI. The water depth in the SNI area is between 60 and 75 metres, but there are few bathymetric profiles available. The seafloor reflection in SNI is discontinuous and high-amplitude, and the accuracy of the sea-floor horizon is therefore poor. The imaging and resolution increases with depth, and salt domes and channels are identified between 0.2 and $0.5 \mathrm{~s}$ (c. 160 to 410 metres below sea surface). However, there are no easily mappable reflections in this $3 \mathrm{D}$-volume. Shal- low channels and shallow salt domes are well imaged on time horizons (Fig. 12). However, the channels are often difficult to interpret. The identified channels are fairly straight and trend E-W. Three major salt domes are clearly identified in cross-section and time slices in SNI (Figs. 12, 13). These salt domes control the morphology of the area as the channels are located between the dome structures. There is a marked change in the channel direction in the shallowest time slices, with several $\mathrm{N}-\mathrm{S}$-trending features.

Similar seismic structures as identified in the SNII and SNI areas are also identified elsewhere in the study area (Fig. 13). The major features are tunnel valleys and salt domes, but outwash plains and lakes (or subglacial depressions) are also tentatively interpreted. In the southwestern part of the area dendritic drainage is also observed. The overall channel trend is $\mathrm{N}-\mathrm{S}$ in the southernmost part and more $\mathrm{E}-\mathrm{W}$ in the northernmost part (Fig. 13).

\section{Discussion}

Although sampling was discontinuous, important information was obtained from the sedimentological, paleontological and geochronological analyses of samples from well 3/6-1.

In the sandy interval below $12 \mathrm{~m}$ there are practically no foraminifera and no material that can be carbon dated. Knudsen (2000) suggested that at least some of this succession could be near-shore marine deposits from the Eemian interglacial. The silty interval from 10.0 to 11.0 $\mathrm{m}$ was interpreted as marine Weichselian by Knudsen (2000). This is supported by the rich, marine, cold-water fauna in sample 11A and the radiocarbon date of 38,400 ${ }^{14} \mathrm{C}^{\mathrm{y}} \mathrm{rs}$ (42 kyr cal BP), but there is no IRD. The dating was based on a small, robust coal particle that could be reworked, so a younger age for this sample is possible. 

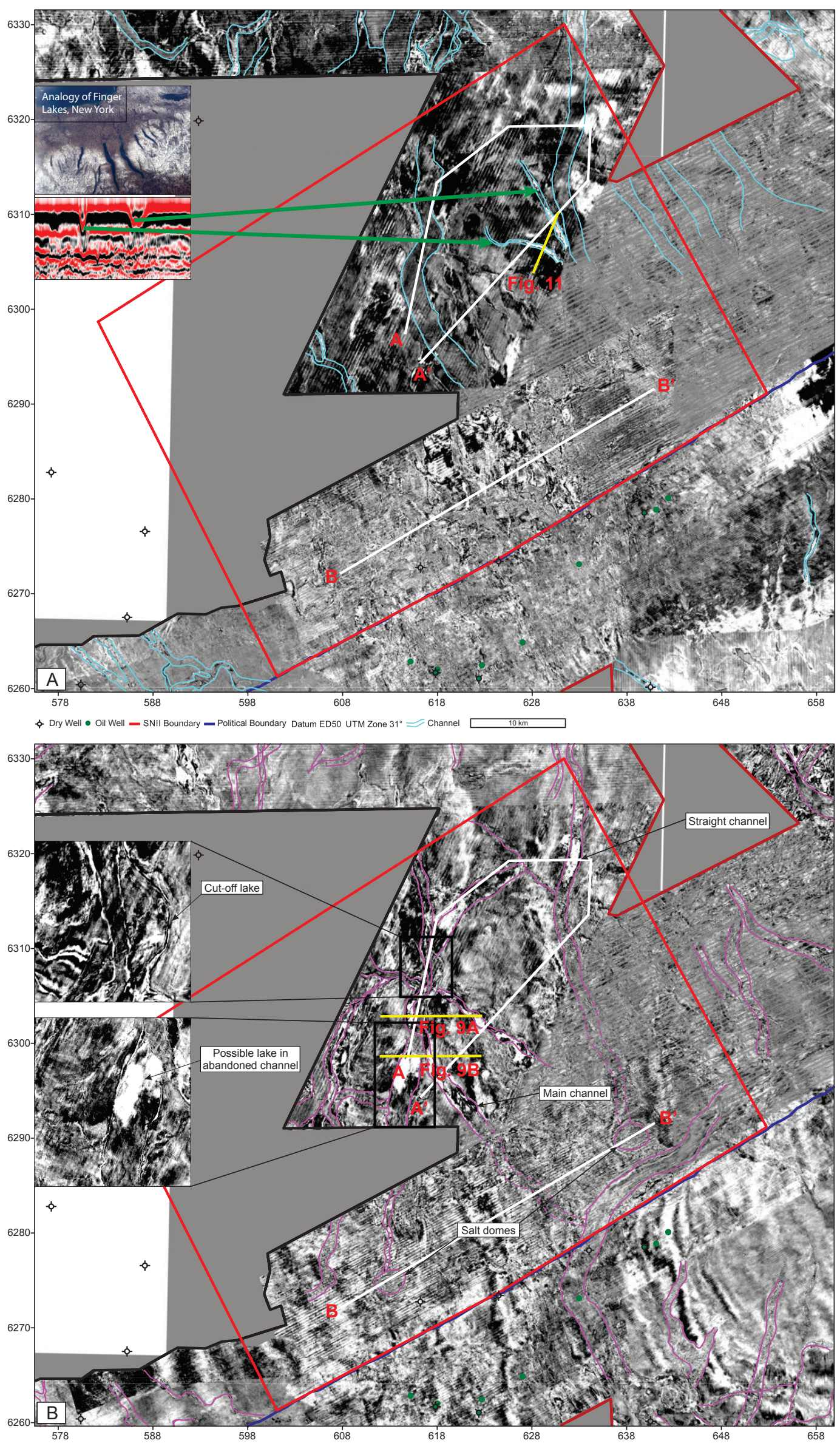

Figure 10. Interpreted seismic time slices at (A) $45 \mathrm{mbsf}(0.140 \mathrm{~s})$ and (B) $155 \mathrm{mbsf}(0.272 \mathrm{~s})$ in SNII, showing clear N-S-trending channel systems and two major salt domes. Two possible lakes are also interpreted. The levels of both time slices are shown in Fig. $8 \mathrm{C}, D$. 


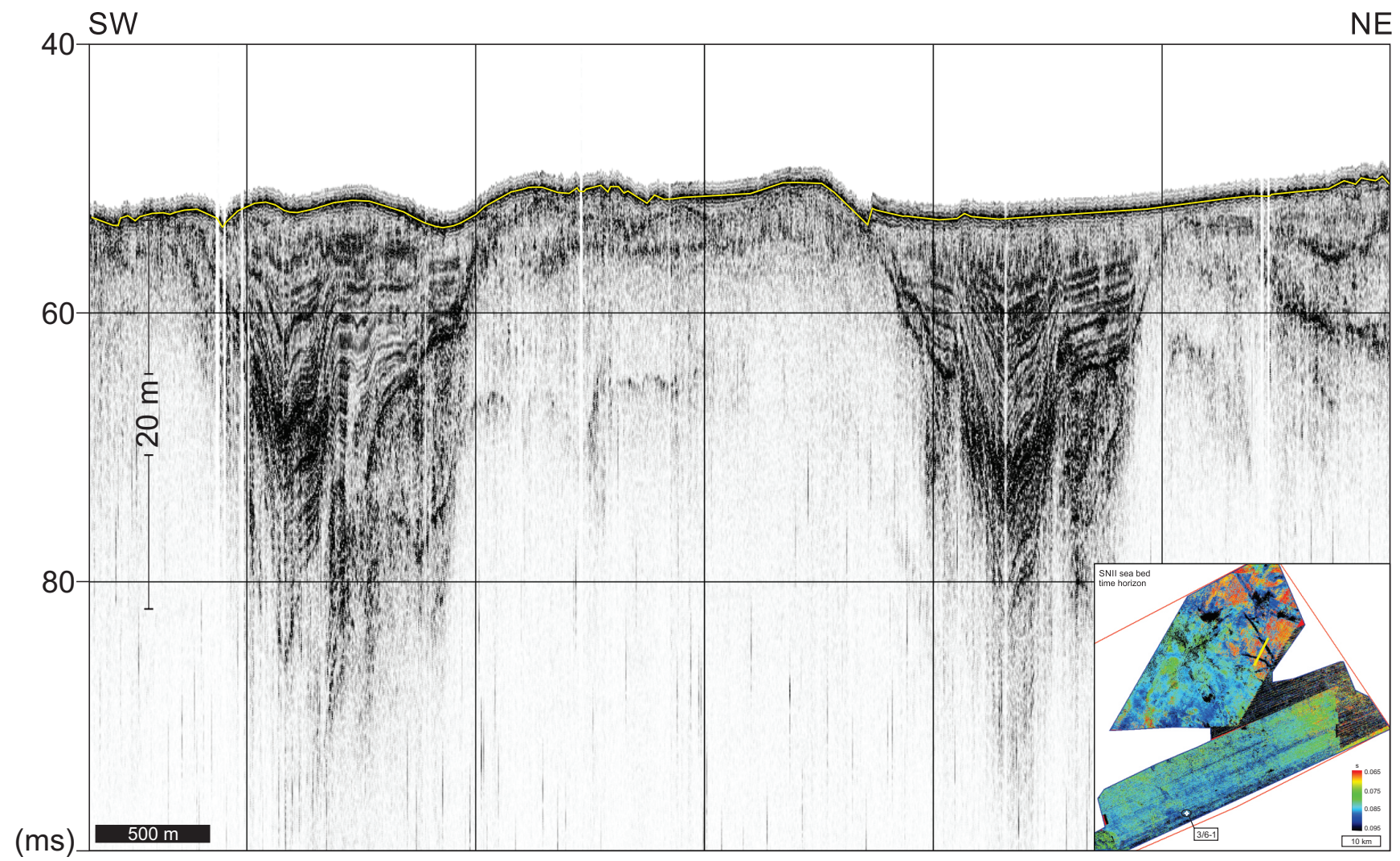

Figure 11. TOPAS subbottom profiler line across the V-shaped channels in SNII (cf., Fig. 9). Note thin or absent Holocene on the highs. The location of the seismic profile is shown in Figs. 2 \& 10A.

Unit III (2.6-10 m) was suggested by Knudsen (2000) to represent Middle-Late Weichselian glacio-lacustrine (periglacial) clay, which is likely, although the very sparse but seemingly unreworked marine fauna of arctic character and the lack of IRD are difficult to explain. The abun- dant freshwater algae (Botryococcus and Pediastrum) support the glacio-lacustrine hypothesis. The palynology of the $4 \mathrm{AB}$ sample $(3.03-3.15 \mathrm{~m})$ also indicates a strong freshwater influence, but the fauna is transitory between Unit III and the overlying Unit II. The foraminiferal
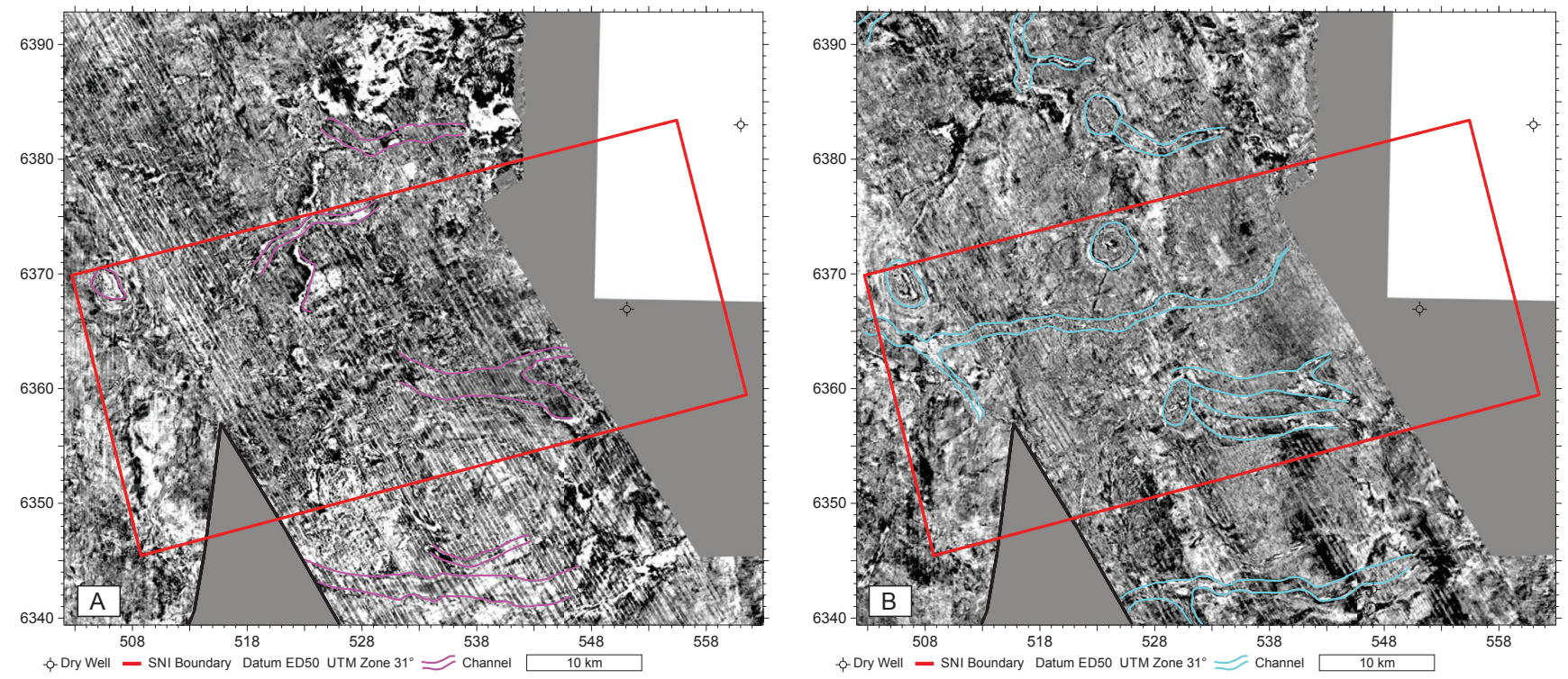

Figure 12. Interpreted seismic time slices at (A) $155 \mathrm{mbsf}(0.272 \mathrm{~s}$ ) and (B) $230 \mathrm{mbsf}$ (0.356 s) in SNI, showing E-W-trending channel systems and four major salt domes. 

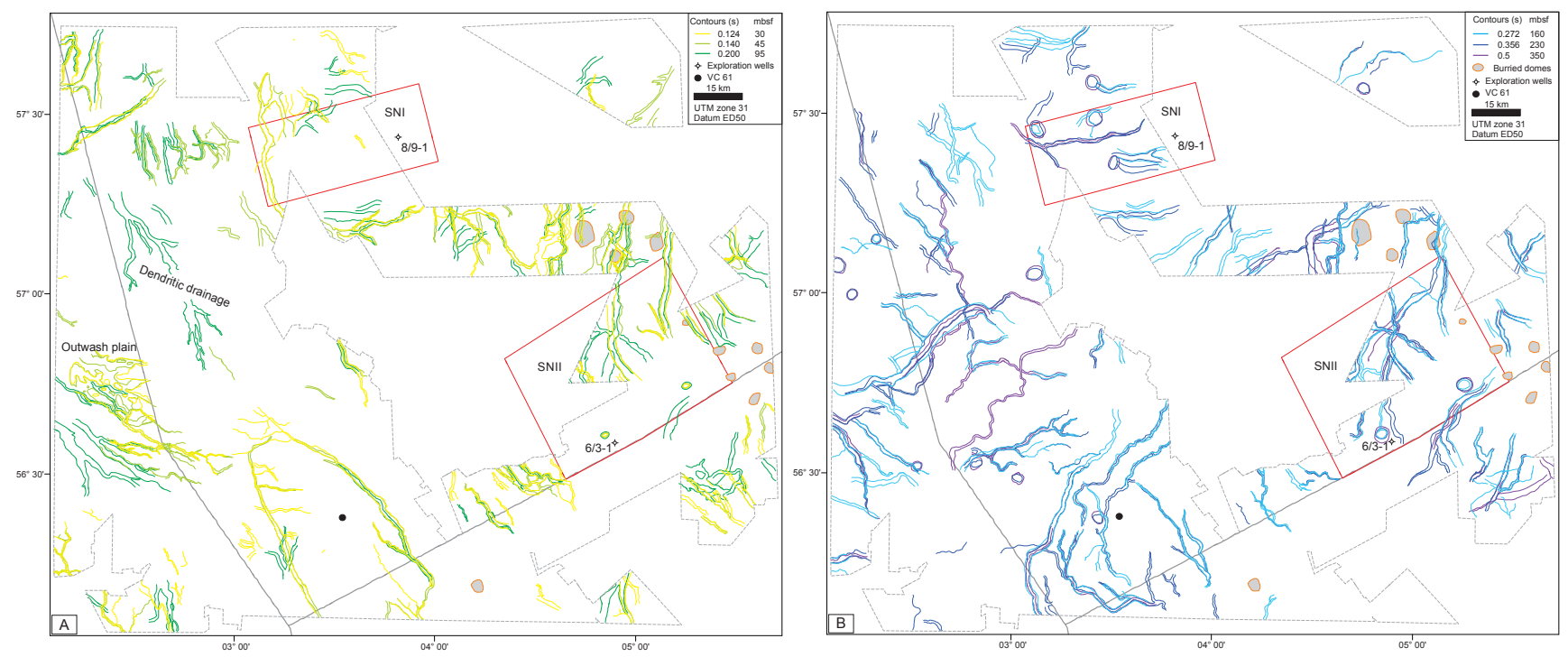

Figure 13. Interpreted tunnel valleys and salt domes at different depths in the whole study area. (A) depth interval 30-95 mbsf and (B) depth interval 160-350 mbsf. N-S or NNW-SSE-trending channels dominate; however, $E-W$-trending tunnel valleys are common at deeper levels in the eastern and southern regions (lower figure).

fauna has a somewhat colder aspect than the overlying unit.

Units I and II, 0-2.6 m, are sandy with a micro- and macrofauna typical of the present normal-marine North Sea at depths from 7 to $60 \mathrm{~m}$. As clearly shown by the radiocarbon dates, this interval is Holocene, with stable, warm conditions similar to the present.

Hence, a periglacial, possibly ice-dammed lake or estuary seems to have covered the SNII site during some interval after the $38.4 \mathrm{ka}$ BP age at $10 \mathrm{~m}$ core depth. No direct evidence of dry land, such as peat, was found in the samples. The timing of this interval with respect to possible erosion during LGM, ending at c. $20 \mathrm{ka} \mathrm{BP}$, is uncertain. In any case, marine inundation took place between $13.414 \mathrm{C}$ ka BP (15.8 kyr BP calibrated; sample 4AB) and 9.24 14C ka BP (10.1 kyr BP calibrated; sample 4AB), probably closer to the latter. This fits well with the $10.2 \mathrm{kyr}$ time slice map of Gyllencreutz et al. (2006), where the coastline is indicated close to the $3 / 6-1$ well site.

In the VC61 core, taken somewhat farther to the west in SNII, we see a similar development as in 3/6-1 but much condensed, possibly because of the poor recovery. The sandy upper Unit A, $0-42 \mathrm{~cm}$, is normal marine with a modern, fully-marine fauna typically found from below the tidal zone and down to present-day water depth. This interval, correlating with Units I-II in 3/6-1, is sedimentologically rather homogeneous, but the slight down-core increase in grain size and IRD may reflect progressively more near-shore and/or colder conditions down core.

The lower Unit B, below $42 \mathrm{~cm}$, is also marine, but less well sorted. The fragmented shells indicate relatively high energy. The clay pipes and flasers are difficult to inter- pret, but may be connected with tidal sedimentation. No typical littoral species were found, nor any obvious plant fragments, but both the foraminiferal (low diversity, Elphidium dominated) and the molluscan (mainly Mya) fauna are typical of estuarine, low-salinity environments. The dominance of Elphidium is reminiscent of the Heligoland Channel Zone D of Konradi (2000), which he interpreted as tidal flat to subtidal, estuarine, c. 11-10 kyr cal BP, and also zone R2 of the Danish sector of the central North Sea (Knudsen, 1985).

Of special interest is the Barnea candida at $37 \mathrm{~cm}$. This is a boring bivalve, often living in wood or peat. The fragile shell is extremely well preserved, making long transport unlikely, and supports a near-shore interpretation.

We have constructed a paleoenvironmental model for the SNII area constrained by well data, regional ice models and global temperature and sea-level curves (Fig. 14). This is clearly a simplified model which does not consider isostatic postglacial readjustment of the area. Late Weichselian and Holocene shorelines reconstructed from glacio-isostatic models of the North Sea area are given by Lambeck (1995).

The extent of Weichselian ice sheets in the North Sea is known in general terms but details are still lacking (Sejrup et al., 2009, 2015). A continuous ice sheet across the North Sea during the LGM may have led to the formation of a dammed lake in the central North Sea (e.g., Andersen, 2000). According to Graham et al. (2011), initial deglaciation occurred at 24-22 kyrs BP followed by several readvances. However, these readvances did not cover the whole North Sea. From 22 to $14.5 \mathrm{kyr}$ BP the sea level was relatively steady and the temperature curve shows a cold and dry period with glacio-lacustrine environments and 


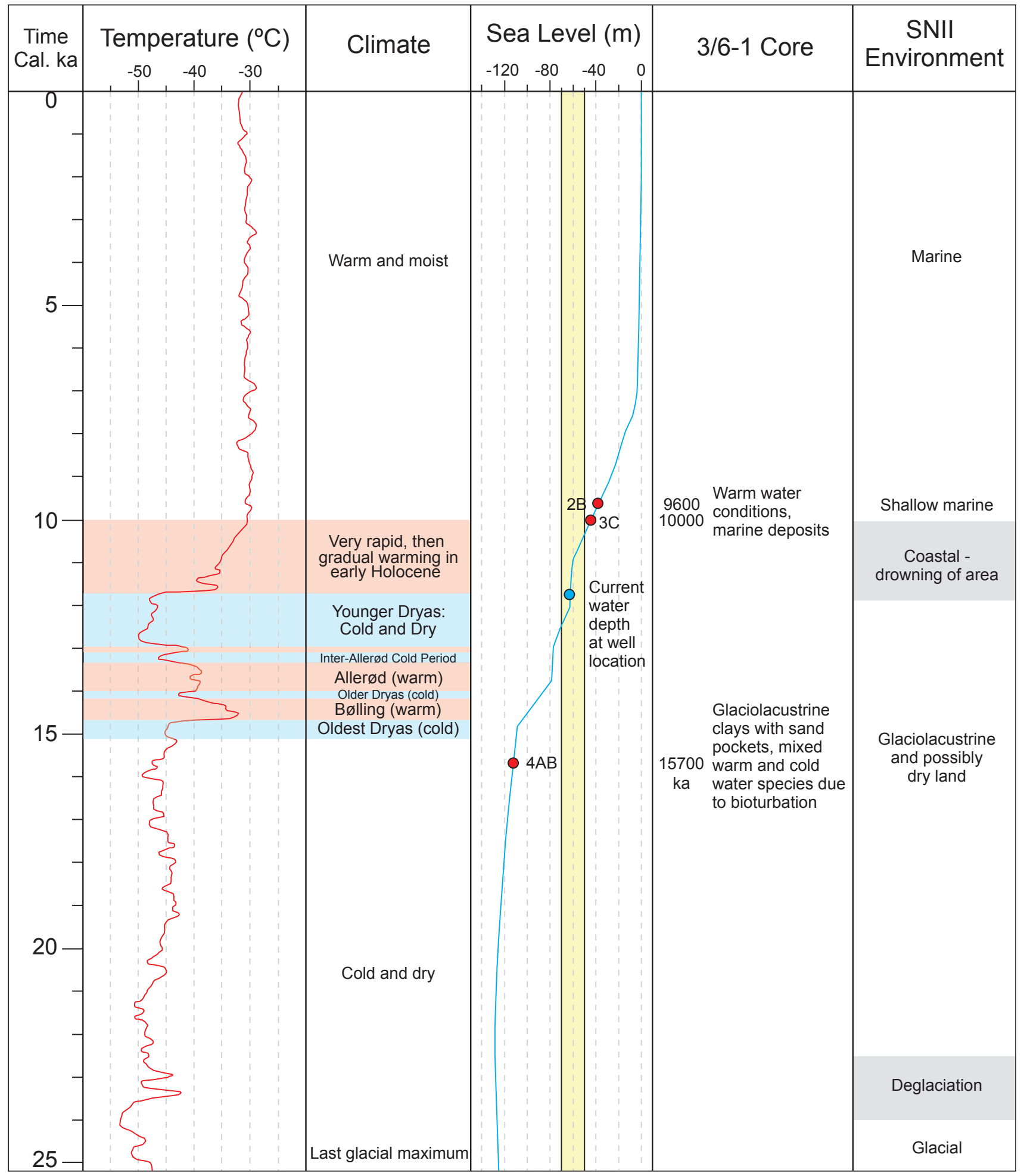

Figure 14. Postglacial paleoenvironmental model for the SNII area. The temperature curve is from the Greenland ice core GRIP2 (http://www. ncdc.noaa.gov/pale/recons.html). The global sea-level curve is modified from Fleming et al. (1998), Fleming (2000) and Milne et al. (2005). Climate data compiled from http://www.esd.ornl.gov/projects/qen/nercEurope.html, Graham et al. (2011) and Lambeck et al. (2002).

possibly dry land with braided streams at the front of ice margins (Fig. 14). Time slices generated at different depths show such fluvial channels in the study area.

After the Oldest Dryas, several short warm and moist periods (Bølling-Allerød) began at about $14 \mathrm{kyr}$ BP. The temperature increased by almost $15^{\circ} \mathrm{C}$ after the cold Younger Dryas (12.8-11.5 kyr BP) with a rapid rise of sea level from ice melting. Still, the sea level was likely not high enough to drown the SNII area. A coastal area occupied the study area $11 \mathrm{kyr}$ BP at the start of the Holocene, as also predicted by Lambeck (1995). 


\section{Conclusions}

The southern Norwegian sector of the North Sea has been a focus area for petroleum activities since the 1970s. It is therefore surprising that very little bathymetry, seabed soil samples, and high-resolution seismic data exist in this area. The main aim of this study was to find out if there was dry land suitable for human occupation in postglacial times in the southern Norwegian North Sea. The available seismic data are not of sufficient volume or resolution to answer this question. However, the identification of tunnel valleys strongly suggests that both SNI and SNII were covered by ice periodically during the past few hundred thousand years (MIS10-8, MIS 6 and MIS 2).

Even so, it is clear from core data that dry, unglaciated land with potential for human habitation was at least possible in the SNII area in the Oldest, Older and Younger Dryas cold periods, but also in the warm and moist Bølling and Allerød periods. This result is consistent with the glacioisostatic modelling of Lambeck (1995). Pleistocene terrestrial phases can be inferred from the interpreted fluvial and lacustrine landforms in the seismic images. However, with the limited material available we have not been able to find direct evidence of terrestrial soil or terrestrial macrofossils in cores. Still, there is indirect evidence in core 3/6-1 for glaciolacustrine conditions in the Mid to Late Weichselian, followed by marine inundation between 15.8 and 10.1 kyr BP but probably closer to the latter date. The core VC61 contains sedimentological and faunal evidence for estuarine conditions in its lower part, presumably of Early Holocene age.

By analogy with similar areas such as Beringia, and with reference to the archeological finds in Vest-Agder, Norway, we suggest the name Agderia for this Norwegian part of Doggerland. Together with the Viking Bank area to the north, Agderia is an intriguing and little studied area with respect to possible human settlement, and deserves a more detailed study in the future. In particular, it will be important to acquire ultrahigh-resolution, shallow seismic data and multiple, continuous cores to at least $4 \mathrm{~m}$ depth in order to penetrate the Holocene marine sands.

Acknowledgements. The extensive 3D seismic database was kindly provided by PGS, and site survey data and soil borings by Eni and Gardline. Olex gave access to the shared bathymetric database. The input and support of the project group, Jostein Gundersen and Håkon Glørstad (Maritime Museum and University of Oslo) are greatly appreciated. In addition, Johan Petter Nystuen (University of Oslo), Haflidi Haflidason and Hans Petter Sejrup (University of Bergen), Carl Fredrik Forsberg and Maarten Vanneste (NGI), Laurent Gernigon (NGU), Tor Inge Tjelta (Forewind), and Willy Fjeldskaar (TectoNor) gave important input to the study. Special thanks to Timme Donders at TNO for palynology, and to Gardline Geosciences for access to the VC61 core. This work was partly supported by the Research Council of Norway through its Centres of Excellence funding scheme, project number 223272. An anonymous reviewer provided useful comments on the manuscript.

\section{Reference list}

Andersen, B.G. 2000: Istider i Norge. Universitetsforlaget, Oslo, 216 pp. Beets, D.J., Meijer, T., Beets, C.J., Cleveringa, P., Laban, C. \& van der Spek, A.J.F. 2005: Evidence for a Middle Pleistocene glaciation of MIS 8 age in the southern North Sea. Quaternary International 133, 7-19. doi: 10.1016/j.quaint.2004.10.002.

Bicket, A. 2011: Submerged prehistory: Research in context. Marine Aggregate Levy Sustainability Fund, Science Monograph Series 5, Wessex Archaeology, Edinburgh, 66 pp.

Bird, M.I., Taylor, D. \& Hunt, C. 2005: Palaeoenvironments of insular Southeast Asia during the Last Glacial Period: a savanna corridor in Sundaland? Quaternary Science Reviews 24, 2228-2242. doi: 10.1016/j. quascirev.2005.04.004.

Coles, B.J. 1998: Doggerland: a speculative survey. Proceedings of the Prehis toric Society $64,45-81$.

Cornwell, J.D. \& Carruthers, R.M. 1986: Geophysical studies of a buried valley system near Ixworth, Suffolk. Proceedings of the Geologists' Association 97, 357-364. doi: 10.1016/S0016-7878(86)80027-X.

Donders, T.H., Bunnik, F.P.M. \& Koolmees, H. 2011: Pollen analysis of samples from Doggerland (well site 3/6-1). TNO Petroleum Geoscience Report, 7 pp.

Fitch, S., Thomson, K. \& Gaffney, V. 2005: Late Pleistocene and Holocene depositional systems and the palaeogeography of the Dogger Bank, North Sea. Quaternary Research 64, 185-196. doi: 10.1016/j. yqres.2005.03.007.

Fleming, K. 2000: Glacial rebound and sea-level change constraints on the Greenland ice sheet. $\mathrm{PhD}$ thesis, Australian National University, $568 \mathrm{pp}$.

Fleming, K., Johnston, P., Zwartz, D., Yokoyama, Y., Lambeck, K. \& Chappell, J. 1998: Refining the eustatic sea-level curve since the Last Glacial Maximum using far- and intermediate-field sites. Earth and Planetary Science Letters 163, 327-342. doi: 10.1016/S0012-821X(98)00198-8.

Fugro 2000: Soil investigation and spud can penetration analysis. Fugro Report 03319-2, 113 pp.

Gabriel, G., Kirsch, R., Siemon, B. \& Wiederhold, H. 2003: Geophysical investigation of buried Pleistocene subglacial valleys in Northern Germany. Journal of Applied Geophysics 53, 159-180. doi: 10.1016/j. jappgeo.2003.08.005.

Gaffney, V., Thomson, K. \& Fitch, S. 2007: Mapping Doggerland, the Mesolithic landscapes of the southern North Sea. Archaeopress, Oxford, 131 pp.

Gaffney, V., Fitch, S. \& Smith, D. 2009: Europe's lost world: the rediscovery of Doggerland. Council for British Archaeology Research Report 160, 202 pp.

Glørstad, H. 2016: Deglaciation, sea-level change and the Holocene colonization of Norway. Geological Society of London Special Publications 411, 9-25. doi: 10.1144/SP411.7.

Glørstad, H. \& Kvalø, F. 2012: HAVVIND - Paleogeografi og arkeologi. Norsk Maritimt Museum - arkeologisk rapport 2012:12, 98 pp.

Graham, A.G.C., Lonergan, L. \& Stoker, M.S. 2007: Evidence for Late Pleistocene ice stream activity in the Witch Ground Basin, central North Sea, from 3D seismic reflection data. Quaternary Science Reviews 26, 627-643. doi: 10.1016/j.quascirev.2006.11.004.

Graham, A.G.C., Lonergan, L. \& Stoker, M.S. 2010: Depositional environments and chronology of Late Weichselian glaciation and deglaciation in the central North Sea. Boreas 39, 471-491. doi: 10.1111/j.15023885.2010.00144.x

Graham, A.G.C., Stoker, M.S., Lonergan, L., Bradwell, T. \& Stewart, M.A. 2011: The Pleistocene glaciations of the North Sea Basin. Developments in Quaternary Science 15, 261-278. doi: 10.1016/B978-0-444-534477.00021-0.

Grøn, O. \& Mortensen, L.F. 2011: Stone Age in the Danish North Sea sector. Maritime Archaeology Newsletter from Denmark 26, 3-8.

Gyllencreutz, R., Backman, J., Jakobsson, M., Kissel, C. \& Arnold, E. 2006: Postglacial palaeoceanography in the Skagerrak. The Holocene 16, 975-985. doi: 10.1177/0959683606hl988rp.

Hjelstuen, B.O., Sejrup, H.P., Haflidason, H., Schäuble, C., Wiberg, D.H., Aadneram, J., Monsen, S., Lehn-Nilsen, E., O’Cofaigh, C. \& Livingstone, S. 2012: Marine Geological Cruise Report from the Norwegian Channel. Department of Earth Science, University of Bergen, Report No. 100-02/12, $66 \mathrm{pp}$.

Hovland, M. \& Dukefoss, K.M. 1981: A submerged beach between Norway and Ekofisk in the North Sea. Marine Geology 43, M19-M28. doi: 
10.1016/0025-3227(81)90123-7.

Huuse, M. \& Lykke-Andersen, H. 2000: Overdeepened Quaternary valleys in the eastern Danish North Sea: morphology and origin. Quaternary Science Reviews 19, 1233-1253. doi: 10.1016/S0277-3791(99)00103-1.

Huuse, M., Lykke-Andersen, H. \& Michalsen, O. 2001: Cenozoic evolution of the eastern Danish North Sea. Marine Geology 177, 243-269. doi:10.1016/S0025-3227(01)00168-2.

Jørgensen, F. \& Sandersen, P.E. 2006: Buried and open tunnel valleys in Denmark - erosion beneath multiple ice sheets. Quaternary Science Reviews 25, 1339-1363. doi:10.1016/j.quascirev.2005.11.006.

Jørgensen, F., Lykke-Andersen, H., Sandersen, P.B.E., Auken, E. \& Nørmark, E. 2003: Geophysical investigations of buried Quaternary valleys in Denmark: an integrated application of transient electromagnetic soundings, reflection seismic surveys and exploratory drillings. Journal of Applied Geophysics 53, 215-228. doi: 10.1016/j.jappgeo.2003.08.017.

Kaiser, K., Rother, H., Lorenz, S., Gärtner, P. \& Papenroth, R. 2007: Geomorphic evolution of small river-lake systems in northeast Germany during the Late Quaternary. Earth Surface Processes and Landforms 32, 1516-1532. doi: 10.1002/esp.1480.

Kluiving, S.J., Bosch, J.H.A., Ebbing, J.H.J., Mesdag, C.S. \& Westerhoff, R.S. 2003: Onshore and offshore seismic and lithostratigraphic analysis of a deeply incised Quaternary buried valley system in the Northern Netherlands. Journal of Applied Geophysics 53, 249-271. doi: 10.1016/j. jappgeo.2003.08.002.

Knudsen, K.L. 1985: Foraminiferal stratigraphy of Quaternary deposits in the Roar, Skjold and Dan fields, central North Sea. Boreas 14,311-324. doi: 10.1111/j.1502-3885.1985.tb00919.x.

Knudsen, K.L. 2000: Internal report on foraminiferal analysis. Norsk Agip, Norwegian well 3/6-1,6 pp.

Kolla, V., Posamentier, H.W. \& Wood, L.J. 2007: Deep water and fluvial sinuous channels - characteristics, similarities and dissimilarities and modes of formation. Marine and Petroleum Geology 24,388-405. doi: 10.1016/j. marpetgeo.2007.01.007.

Konradi, P.D. 2000: Biostratigraphy and environment of the Holocene marine transgression in the Heligoland Channel, North Sea. Bulletin of the Geological Society of Denmark 47, 71-79.

Kristensen, T.B., Piotrowski, J.A., Huuse, M., Clausen, O.R. \& Hamberg, L. 2008: Time-transgressive tunnel valley formation indicated by infill sediment structure, North Sea - the role of glaciohydraulic supercooling. Earth Surface Processes and Landforms 33, 546-559. doi: 10.1002/ esp. 1668 .

Krohn, C.F., Larsen, N.K., Kronborg, C., Nielsen, O.B. \& Knudsen, K.L. 2009: Litho- and chronostratigraphy of the Late Weichselian in Vendsyssel, northern Denmark, with special emphasis on tunnel valley infill in relation to a receding ice margin. Boreas 38, 811-833. doi: 10.1111/j.15023885.2009.00104.x.

Kuhlmann, G. \& Wong, T.E. 2008: Pliocene paleoenvironment evolution as interpreted from 3D-seismic data in the southern North Sea, Dutch offshore sector. Marine and Petroleum Geology 25, 173-189. doi: 10.1016/j. marpetgeo.2007.05.009.

Lambeck, K. 1995: Late Devensian and Holocene shorelines of the British Isles and North Sea from models of glacio-hydro-isostatic rebound. Journal of the Geological Society of London 152, 437-448. doi: 10.1144/ gsjgs.152.3.0437.

Lambeck, K., Yokoyama, Y. \& Purcell, T. 2002: Into and out of the Last Glacial Maximum: sea-level change during Oxygen Isotope Stages 3 and 2. Quaternary Science Reviews 21, 343-360. doi: 10.1016/S02773791(01)00071-3.

Leth, J.O. 2003: Nordsøen efter istiden; udforskningen af Jyske Rev. Geolog Nyt fra GEUS no. 3 2003, Geological Survey of Denmark.

Liu, A.C., Missiaen, T. \& Henriet, J.P. 1992: The morphology of the topTertiary erosion surface in the Belgian sector of the North Sea. Marine Geology 105, 275-284. doi: 10.1016/0025-3227(92)90193-L.

Lonergan, L., Maidment, S.C.R. \& Collier, J.S. 2006: Pleistocene subglacial tunnel valleys in the central North Sea basin: 3-D morphology and evolution. Journal of Quaternary Science 21, 891-903. doi: 10.1002/jqs.1015.

Long, D. 1992: Devensian late-glacial gas escape in the central North Sea. Continental Shelf Research 12, 1097-1110. doi: 10.1016/02784343(92)90071-Q.

Milne, G.A., Long, A.J. \& Bassett, S.A. 2005: Modelling Holocene relative sea-level observations from the Caribbean and South America.
Quaternary Science Reviews 24, 1183-1202. doi: 10.1016/j.quascirev.2004.10.005.

Møller, M.J., Olsen, H., Ploug, C. \& Hjorth, H. 2007: Gravity field separation and mapping of buried Quaternary valleys in Lolland, Denmark using old geophysical data. Journal of Geodynamics 43, 330-337. doi: 10.1016/j.jog.2006.09.021.

Nymoen, P. \& Skar, B. 2011: The unappreciated cultural landscape indications of submerged Mesolithic settlement along the Norwegian southern coast. In Benjamin, J., Bonsall, C., Pickard, C. \& Fischer, A. (eds.): Underwater Archaeology and the Submerged Prehistory of Europe, Oxbow Books, pp. 38-54.

Piotrowski, J.A. 1994: Tunnel-valley formation in northwest Germany geology, mechanisms of formation and subglacial bed conditions for the Bornhöved tunnel valley. Sedimentary Geology 89, 107-141. doi: 10.1016/0037-0738(94)90086-8.

Planke, S. \& Berndt, C. 2007: Apparatus for seismic measurements. US Patent no. US 7,221,620 B2

Praeg, D. 1996: Morphology, stratigraphy and genesis of buried MidPleistocene tunnel valleys in the southern North Sea Basin. PhD thesis, University of Edinburgh, $430 \mathrm{pp}$.

Praeg, D. 2003: Seismic imaging of mid-Pleistocene tunnel-valleys in the North Sea Basin - High resolution from low frequencies. Journal of Applied Geophysics 53, 273-298. doi: 10.1016/j.jappgeo.2003.08.001.

Reimer, P.J., Bard, E., Bayliss, A., Beck, J.W., Blackwell, P.G., Bronk Ramsey, C., Buck, C.E., Cheng, H., Edwards, R.L., Friedrich, M., Grootes, P.M., Guilderson, T.P., Haflidason, H., Hajdas, I., Hatté, C., Heaton, T.J., Hogg, A.G., Hughen, K.A., Kaiser, K.F., Kromer, B., Manning, S.W., Niu, M., Reimer, R.W., Richards, D.A., Scott, E.M., Southon, J.R., Turney, C.S.M. \& van der Plicht, J. 2013: IntCal13 and MARINE13 radiocarbon age calibration curves 0-50,000 years cal BP. Radiocarbon 55, 1869-1887. doi: 10.2458/azu_js_rc.55.16947.

Sejrup, H.P., Nygård, A., Hall, A.M. \& Haflidason, H. 2009: Middle and late Weichselian (Devensian) glaciation history of south-western Norway, North Sea and eastern UK. Quaternary Science Reviews 28, 370-380. doi: 10.1016/j.quascirev.2008.10.019.

Sejrup, H.P., Hjelstuen, B.O., Nygård, A., Haflidason, H. \& Mardal, I. 2015: Late Devensian ice marginal features in the central North Sea processes and chronology. Boreas 44,1-13. doi: 10.1111/bor.12090.

Sellevold, B.J. \& Skar, B. 1999: The First Lady of Norway. In Gundhus, G., Seip, E. \& Ulriksen, E. (eds.): NIKU 1994-1999. Kulturminneforskningens mangfold, Norsk institutt for kulturminneforskning Temahefte 31, pp. 6-11.

Shennan, I., Lambeck, K., Flather, R., Horton, B., Mcarthur, J., Innes, J., Lloyd, J., Rutherford, M. \& Wingfield, R. 2000: Modelling western North Sea palaeogeographies and tidal changes during the Holocene. Geological Society of London Special Publications 166, 299-319. doi: 10.1144/GSL. SP.2000.166.01.15.

Stewart, M.A. \& Lonergan, L. 2011: Seven glacial cycles in the middle-late Pleistocene of northwest Europe: Geomorphic evidence from buried tunnel valleys. Geological Society of America 39, 283-286. doi: 10.1130/ G31631.1.

Stuiver, M., Reimer, P.J. \& Reimer, R.W. 2005: CALIB 5.0. [WWW program and documentation].

Weninger, B., Schulting, R., Bradtmöller, M., Clare, L., Collard, M., Edinborough, K., Hilpert, J., Jöris, O., Niekus, M., Rohling, E.J. \& Wagner, B. 2008 : The catastrophic final flooding of Doggerland by the Storegga Slide tsunami. Documenta Praehistorica 35, 1-24.

West, F.H. (ed.) 1996: American beginnings: The prehistory and palaeoecology of Beringia. University of Chicago Press, $576 \mathrm{pp}$.

Wingfield, R. 1990: The origin of major incisions within the Pleistocene deposits of the North Sea. Marine Geology 91,31-52. doi: 10.1016/00253227(90)90131-3.

Wolters, S., Zeiler, M. \& Bungenstock, F. 2010: Early Holocene environmental history of sunken landscapes: pollen, plant macrofossil and geochemical analyses from the Borkum Riffgrund, southern North Sea. International Journal of Earth Sciences 99, 1707-1719. doi: 10.1007/ s00531-009-0477-6.

Wysota, W., Lankauf, K.R., Szmanda, J., Chruscinska, A., Oczkowski, H.L. \& Przegietka, K.R. 2002: Chronology of the Vistulian (Weichselian) glacial events in the lower Vistula region, middle-north Poland. Geochronometria 21, 137-142. 